\title{
A redescription of Chasmataspis laurencii Caster \& Brooks, 1956 (Chelicerata: Chasmataspidida) from the Middle Ordovician of Tennessee, USA, with remarks on chasmataspid phylogeny
}

\author{
Jason A. Dunlop, Lyall I. Anderson and Simon J. Braddy
}

\begin{abstract}
The type material of Chasmataspis laurencii Caster \& Brooks, 1956 (Chelicerata: Chasmataspidida) from the Middle Ordovician (Tremadoc to Caradoc) of Sevier County, Tennessee, USA, is redescribed, and comparisons are drawn with recently discovered Devonian chasmataspids from Scotland, Germany and Russia. The depositional setting of the C. laurencii fossils is reinterpreted as an ash fall into shallow marine/tidal sediments. Chasmataspis laurencii confirms the presence of 13 opisthosomal segments in Chasmataspidida, a character of unresolved polarity. The phylogenetic position of $C$. laurencii is difficult to resolve. A monophyletic Chasmataspidida has one convincing autapomorphy in the nine-segmented postabdomen, but $C$. laurencii shares a number of characters with xiphosurans (i.e. cardiac lobe, pre-abdomen with axial region, biramous and chelate limbs), while the Devonian taxa more closely resemble eurypterids (i.e. through pediform limbs and a genital appendage). Earlier interpretations of the respiratory system in C. laurencii appear unconvincing in the light of new evidence from Devonian forms with opisthosomal opercula. Resting impressions of a Chasmataspis-like animal from the Upper Cambrian Hickory Sandstone of Texas, USA, also appear to show evidence of opercula. These Texan fossils could represent the oldest record of Euchelicerata. Two chasmataspid families are recognised, and $C$. laurencii is placed in the monotypic Chasmataspididae Caster \& Brooks, 1956, redefined here on the fused pre-abdominal buckler with an axial region and the narrow, elongate post-abdomen ending in a long, lanceolate telson.
\end{abstract}

KEY WORDS: Arthropod, eurypterid, segmentation, Sevier County, Tremadoc-Caradoc, xiphosuran.

Chasmataspids (Chelicerata: Chasmataspidida) are a littleknown group of Palaeozoic chelicerate arthropods, originally interpreted as unusual xiphosurans (Caster \& Brooks 1956; Størmer 1972). They share characters with both xiphosurans (horseshoe crabs) and eurypterids (sea scorpions), but have a unique, autapomorphic pattern of opisthosomal tagmosis: a reduced first opisthosomal segment (1), a three-segmented preabdominal buckler (2-4) and a narrower, nine-segmented postabdomen (5-13). Based on these characters, Anderson \& Selden (1997) excluded chasmataspids from Xiphosura, all of which have 11 or less opisthosomal segments in which the postabdomen comprises no more than three segments. In eurypterids, the postabdomen comprises five segments. Until recently, only three species of chasmataspid were known: Chasmataspis laurencii Caster \& Brooks, 1956 from the Middle Ordovician of Tennessee, USA, and Diploaspis casteri Størmer, 1972 and Heteroaspis novojilovi Størmer, 1972, both from the Lower Devonian of Alken an der Mosel, Germany. Restudy of the original types in conjunction with newly discovered Alken material (Dunlop et al. 2001) indicates that Heteroaspis Størmer, 1972 is a junior synonym of Diploaspis Størmer, 1972.

Following recent advances, the group now includes Forfarella mitchelli Dunlop, Anderson \& Braddy, 1999 from the Lower Devonian Midland Valley of Scotland and Achanarraspis reedi Anderson, Dunlop \& Trewin, 2000 from the Middle Devonian of Caithness, Scotland. Both of these Scottish species are rather poorly preserved, but show the diagnostic pattern of opisthosomal tagmosis. Another, much better pre- served example is Octoberaspis ushakovi Dunlop, 2002a from the Lower Devonian of the Severnya Zemlya archipelago in the Russian Arctic. Further material from the Lower Devonian of Hombach in the Rhenish Slate Mountains of Germany represents a second Diploaspis species (Poschmann et al. in press) and there is now a Silurian record from Scotland (Tetlie \& Braddy, 2004). Other chasmataspids may exist in museum collections, but reside misidentified as either eurypterids or xiphosurans. For example 'Eurypterus' stoermeri Novojilov, 1959 from the Lower Devonian of Russia looks very much like the Alken chasmataspids (see comments in Størmer 1972). A suggested chasmataspid from Vietnam has been reassigned to Eurypterida (Selden 1993; Braddy et al. 2002), but a possible Brazilian chasmataspid was mentioned by Caster in Beall \& Labandeira (1990, p. 263). The present authors have been unable to trace this Brazilian material, but in summary, recognition of distinctive and recurring chasmataspid morphology has recently provided a useful search tool to re-examine pre-existing collections.

In the present paper, the authors redescribe the type material of $C$. laurencii in the light of recent work on Devonian chasmataspids. Chasmataspis laurencii is the oldest representative of the group (M. Ordovician, Tremadoc-Caradoc) and is also one of the oldest currently known euchelicerates, i.e. all chelicerates excluding pycnogonids. They question previous functional morphological interpretations, in particular of the respiratory system, and discuss the status of Chasmatapidida and its position within Chelicerata. The authors also figure some Upper Cambrian trace fossils from Texas, USA, which 
are interpreted here as ventral impressions from a Chasmataspis-like animal. If their interpretation is correct, these traces indicate an even older record of the Euchelicerata.

\section{Previous work}

Caster \& Brooks (1956) provided a detailed description of Chasmataspis laurencii, figuring some 20 specimens, and presented a reconstruction of the entire dorsal surface, the ventral opisthosoma and some isolated, chelate limbs. They referred their species to a new family, Chasmataspidae Caster \& Brooks, 1956, and a new order of the Xiphosura, Chasmataspida Caster \& Brooks, 1956, Chasmataspis laurencii was included by Crowson et al. (1967) in The Fossil Record. Here the order name was altered to Chasmataspidida to conform to nomenclature recommendations, although this change was not consistently applied by subsequent authors. Bergström (1968) suggested that C. laurencii was a synziphosurine (i.e. a stem-group xiphosuran, terminology after Anderson \& Selden 1997) and did not deserve the status of a separate xiphosuran order. By contrast, Størmer (1972) regarded Chasmataspidida as a valid order within a subclass Xiphosura and interpreted both $C$. laurencii and his new Devonian genera, Diploaspis and Heteroaspis, from Alken an der Mosel as having the unique (i.e. autapomorphic) character of a large, ventral, preabdominal plate, which was presumed to cover the gill region (see section 4.3.3.).

Eldredge (1974) tentatively placed chasmataspids and eurypterids as sister taxa based on similarities in the prosomal appendages, but admitted that the paddles seen in both Diploaspis and many eurypterids could be convergently derived. Bergström (1975) regarded Chasmataspis as a 'eurypterid-like xiphosuran' that was closely related to the synziphosurines (see section 6.1.1.). He also rendered Chasmataspidida sensu Størmer polyphyletic, placing Heteroaspis as Chasmataspidida incertae sedis while excluding Diploaspis from the Xiphosura altogether. Simonetta \& Delle Cave (1978) produced a dendrogram in which Chasmataspidida (restricted to Chasmataspis) formed a clade with the xiphosurans, with a new taxon, Diploaspidida (=Diploaspis), as their sister group. Bergström $(1979,1980)$ continued to regard Chasmataspis and xiphosurans as a natural group, defined on characteristics such as their chelate legs, while Diploaspis was placed close to the origins of non-scorpion arachnids.

Simonetta \& Delle Cave $(1980,1981)$ interpreted both Chasmataspidida and Diploaspidida as having evolved (along with xiphosurans and eurypterids) from among the 'emeraldellids', i.e. the Burgess Shale arachnate Emeraldella, and similarlooking genera such as Molaria and Habelia (see also Delle Cave \& Simonetta 1991). Stürmer \& Bergström (1981) continued to regard Chasmataspidida-again restricted to Chasmataspis-as one of three orders within Xiphosura. Similarly, Selden \& Siveter (1987) and Selden (1993) retained chasmataspids among the horseshoe crabs. Starobogatov (1990) grouped chasmataspids, xiphosurans and a number of problematic Lower Palaeozoic arachnates, which he termed 'strabopids', in a subclass, Limuliones. He essentially showed both Chasmataspis and Diploaspis originating from among these 'strabopids'.

Anderson \& Selden (1997) excluded C. laurencii from Xiphosura, and noted that its somewhat anterior eye position and lack of ophthalmic ridges differentiated it from horseshoe crabs. They suggested that the $C$. laurencii head shield resembles that of the Lower Palaeozoic taxon. Agaspidida (see also comments in Selden \& Dunlop 1998). In contrast to previous polyphyletic interpretations, Dunlop \& Selden (1997) interpreted Chasmataspidida as a monophyletic cade within Chelicerata and proposed the distinctive preabdomen/ postabdomen tagmosis pattern as its principal autapomorphy, although these authors incorrectly cited the number of opisthosomal segments as 12. Dunlop \& Selden (1997) proposed a tentative (Chasmatapsidida (Eurypterida+ Arachnida)) clade, although this was not a robust result, being derived from a single synapomorphy: the supposed presence of a basitarsus podomere in the legs. Chasmataspis laurencii has been briefly mentioned in subsequent papers on Devonian chasmataspids (Dunlop et al. 1999; Anderson et al. 2000; Dunlop 2002a) and is redescribed here as part of ongoing studies into this enigmatic group.

\section{Material and methods}

The holotype (USNM 125099) and the most complete paratype (USNM 125101) of Chasmataspis laurencii were obtained from the United States National Museum (USNM), Smithsonian Institution, USA, along with two further morphologically important specimens, USNM 125100 and 125106, showing details of the ventral plate and the appendages. Specimens were studied under a binocular microscope and drawings were prepared using a camera lucida attachment. Immersing the fossils in $70 \%$ alcohol proved to be useful for clarifying details of the appendages. The Devonian chasmataspids were studied for comparative purposes. Størmer's (1972 types of Diploaspis and Heteroaspis are in the collections of the Naturmuseum und Forschungsinstitut Senckenberg, Frankfurt am Main, Germany with recently discovered material (Dunlop et al. 2001) deposited in the Naturhistorisches Museum Mainz/Landessammlung für Naturkunde RheinlandPfalz, Germany. Forfarella is in the Natural History Museum, London, UK. Achanarraspis is in the geological collections of the University of Aberdeen, UK. Octoberaspis is in the Lithuanian Institute of Geology, Vilnius. A plaster cast of the Hickory Sandstone material (see section 5.0) was kindly provided by Mark Webster (formerly at the Department of Geology, Cincinnati). This cast has been deposited in the arthropod palaeontology collection of the Museum für Naturkunde, Berlin (MB.A. 1084) Extant xiphosurans were also studied for comparative purposes with particular reference to Shultz's (2001) recent morphological descriptions of the living species Limulus polyphemus.

\subsection{Abbreviations}

The following abbreviations are used as standard in the camera lucida drawings: (ad) cuticular apodeme; (ap) anterior projection from the ventral plate; (ax) axial region of preabdomen; (bs) basipod of biramous appendage; (ch) chelate claw; (cl) cardiac lobe; (em) postabdominal epimera; (en) endopod; (ex) exopod; (gn) gnathobase; (gs) genal spine; (le) lateral eye tubercle; (me) median eye tubercle; (mr) marginal rim; (ms) marginal spines; (op) opisthosomal opercula; (pa) prosomal appendages; (po) postabdomen; (ri) ridge demarcating marginal region of prosomal dorsal shield and preabdomen; (ts) telson; and (vp) ventral plate. Opisthosomal segments are numbered from 1 to 13 , plus the telson.

\section{Geological setting}

Caster \& Brooks (1956) presented a detailed account of the stratigraphy and geological setting of the C. laurencii fossils, citing the published field notes of Laurence (1944) as their primary source of information. Laurence had noted that the fossilliferous horizon, which he termed the ' 33 beds', was 
angularly unconformable on the underlying Knox dolomite. Caster \& Brooks (1956) cited this dolomite as being of Ordovician (Canadian) age and assigned the overlying Lenoir Limestone (which does not outcrop at this site) to a younger Ordovician (Chazyan) age. This indicated that the ' 33 beds' represented a lens deposit occupying a depression in the Canadian-Chazyan hiatus or unconformily. Laurence (1944) further subdivided the fossiliferous strata into three units: A, B and $\mathrm{C}$. The lowermost beds (C) consist of what he termed massive, unlaminated pyroclastics. Unit $\mathrm{B}$, which contained the $C$. laurencii fossils, consists of finely laminated sediments in which organic material forms carbonaceous planes at the top of varve-like beds. Finally, unit A consists of reworked volcanic ash and carbonates, and included desiccation-cracked surfaces.

\subsection{Age and depositional environment}

In terms of depositional environment, Laurence (1944) advocated a sink hole model in which sediment was deposited in the deeply eroded, irregular topography of the Knox dolomite. Caster \& Brooks (1956) differed in their interpretation, suggesting that $C$. laurencii was living in the mouth of a large submarine spring, drawing parallels with similar modern environments off the west coast of Florida, USA. The associated fossil fauna consists of a phyllocarid crustacean, Douglasocaris collinsi Caster \& Brooks, 1956, and a problematic fossil described as Cestites mirabilis Caster \& Brooks, 1956 and compared, with reservations, to ctenophorans (comb jellies). Caster \& Brooks (1956) commented on the lack of a typical marine shelly fauna at the site, but also explicitly stated that absence of marine fossils was not proof of a non-marine environment. However, Bergström (1975, p. 298), presumably noting the absence of a typical marine fauna, suggested that C. laurencii may have been a freshwater animal.

The 'sink hole' type locality from which Laurence collected at the Douglas Dam is now covered up and inaccessible ( $S$. Bergström, pers. comm., 2002). However, the Ordovician platform carbonates of this region have been subject to rigorous investigation in recent years (Robertson 1994; Steinhauff \& Walker 1995). From these studies, the present authors can now provide a more accurate stratigraphic date for C. laurencii and a more detailed picture of the depositional setting of this unusual locality.

The Knox dolomite in the area of the Douglas Dam is now considered to be Lower Ordovician in age. The plane of unconformity detailed by Laurence (1944) at the Douglas Dam site corresponds with the Knox unconformity that separates Lower and Middle Ordovician sediments in East Tennessee (Steinhauff \& Walker 1995). The Middle Ordovician sediments belong to the Chickamauga Group, which, in turn, consists of seven formations in the carbonate platform-interior: the Five Oaks (oldest), Lincolnshire, Rockdell, Benboldt, Wardell, Witten and Moccasin (youngest). Exposure of the carbonate platform-margin consists of four formations: Five Oaks, Lenoir, Holston and Rockdell. The position of the fossilbearing lithology, directly abutting as it does against the Knox unconformity, strongly points to it belonging to the Five Oaks Formation. The desiccating cracks reported by Laurence (1944) lend further palaeo-environmental information, and suggest that it is part of the platform-interior suite of sediments. Steinhauff \& Walker (1995) suggested that the maximum water depth experienced on the platform-interior was about $20 \mathrm{~m}$, but that most of the sediments were laid down under only a few metres of water. The remaining sediments in this area are marine, and the overlying units are deltaic. This, coupled with the fine-grained nature of the matrix, suggests that a lagoonal marginal marine setting is the most likely.
Finally, the last clue as to the palaeo-environmental setting of the fauna comes from the record of volcaniclastic input to the system in the form of the pyroclastic deposits recorded by Laurence (1944). Steinhauff \& Walker (1995) detailed one particular facies association found in the platform-interior carbonate sequence that contains bedded bentonites. It would appear that $C$. laurencii was preserved in their facies ' $\mathrm{S}$ ', interpreted as ash falls preserved within shallow, low-energy subtidal and peritidal environments. Depth data for this facies ranged from 0.5 to $15 \mathrm{~m}$. This association of exceptional preservation with ash fall at the Douglas Dam site is paralleled by a recently described example from the Silurian of Herefordshire, England (Orr et al. 2000a, b).

With respect to a stratigraphic age for $C$. laurencii and the other Douglas Dam fossils, Bergström (2000) recently dated the younger Holston Formation (see above) as Caradoc. Ausich (1997) also dated the Holston Formation at $460 \mathrm{Ma}$, which makes it Ordovician in age and (in UK terminology) Early Caradocian. Although the Knox Dolomite is predominantly Upper Cambrian in age, the Cambro-Ordovician boundary lies within the upper reaches of the Dolomite and is not marked by any significant unconformity (Janssens 1973). This means that the fossiliferous horizon could be could be anywhere between the Tremadoc and Caradoc, depending on how high up in the Knox Dolomite the hiatus occurs. The present authors suggest that their fossils lie somewhere between these stratigraphic dates, perhaps late Llandeilian.

\section{Morphological interpretation}

The Chasmataspis laurencii fossils are preserved as either (1) orange-brown impressions on a pale grey-brown matrix (e.g. USNM 125099) or (2) dark grey impressions on a lighter grey matrix (e.g. USNM 125101). With the exception of the enigmatic ventral buckler (see section 4.3.3), the fossils invariably show the dorsal surface (Figs 1-4). Parts and counterpart show the animal in positive and negative relief. Fossils range in total body length from about $4 \mathrm{~cm}$ to $7 \mathrm{~cm}$, suggesting that more than one instar is present. Chasmataspis laurencii has the overall appearance of a horseshoe crab with a long, segmented 'tail'. As Caster \& Brooks (1956) noted, the cuticle appears to be unmineralised and some surface relief is preserved in the form of ridges and tubercles, for example. When examined under high magnification, the cuticle has a micro-ornament of tiny pits. These are most clearly preserved on the opisthosoma and the limbs. Descriptions are of the appearance of the animal in life and are based on a composite of material, with individual specimens noted where appropriate. An overall reconstruction of the dorsal surface of the animal in life is presented in Figure 8.

\subsection{Prosoma}

The prosomal dorsal shield, or carapace (Figs 1-4), is a single, undivided plate, semicircular in outline and with a distinct marginal rim that merges posterolaterally into the genal spines. The marginal rim was described as serrated by Caster \& Brooks (1956), but careful examination suggests that they overstated any marginal serration. The actual margin is rather poorly preserved in places and this can give a misleading impression of serrations. The marginal rim in C. laurencii is ornamented with small, rounded pits and is demarcated from the rest of the dorsal shield by a narrow, c. $0 \cdot 2 \mathrm{~mm}$ wide, ridge which was not mentioned in the original description. This ridge is ornamented with tiny tubercles and forms the inner boundary of the marginal rim. A similar ridge is also present on the dorsal shield of the Russian species O. ushakovi (see Dunlop 2002a for details). 

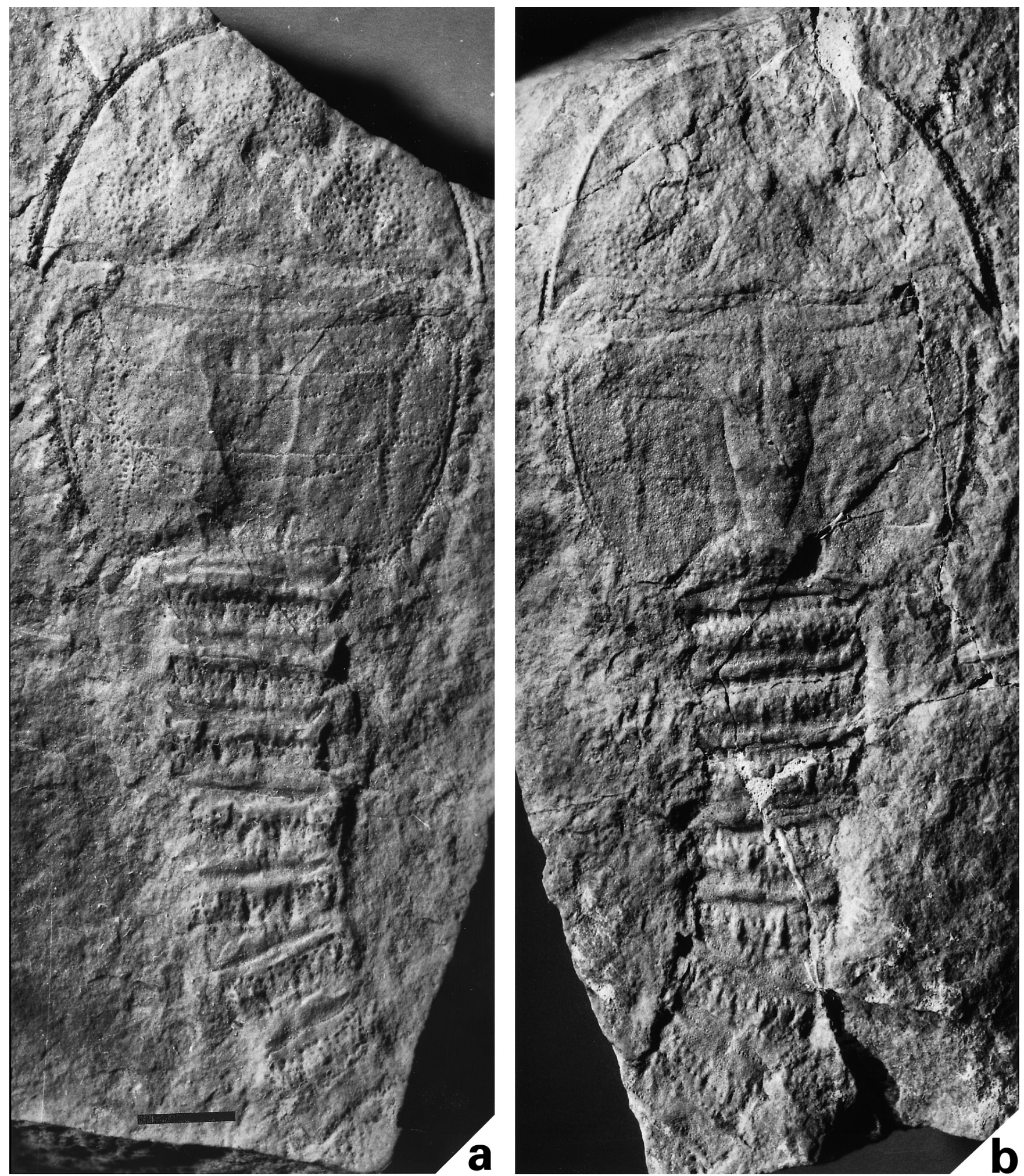

Figure 1 Chasmataspis laurencii Caster \& Brooks, 1956: USNM 125099 (holotype), from the foundations of the Douglas Dam, Sevier County, Tennessee, USA. Probably from the Five Oaks formation of the Chickamauga Group, Middle Ordovician (Tremadoc-Caradoc). An almost complete specimen in dorsal view: (a) part; (b) counterpart. Scale bar $=5 \mathrm{~mm}$.

The posterolateral corners of the dorsal shield - the genal or lateral angles - form prominent, backward-pointing spines (Figs 1-4). These structures have a dorsal ridge, derived in part from the carapace marginal ridge (see above), and so could be classified as genal spines, as defined by Anderson \& Selden (1997, char. 14) for xiphosurans. The posterior margin of the carapace in $C$. laurencii is essentially straight, but makes a shallow, anterior curve near each of the lateral margins before merging with the genal spines. Furthermore, there are small, curving grooves in each posterolateral corner of the dorsal shield, each of which also merge into the genal spine.

The prosomal dorsal shield bears both median and lateral eye tubercles, while much of the carapace is ornamented with small tubercles (diameter c. 100-200 $\mu \mathrm{m}$ ), which Caster \& Brooks (1956) called papillae. These tubercles in the holotype of $C$. laurencii are concentrated in an arcing band towards the middle of the shield (Figs 1,2), becoming less prominent both 


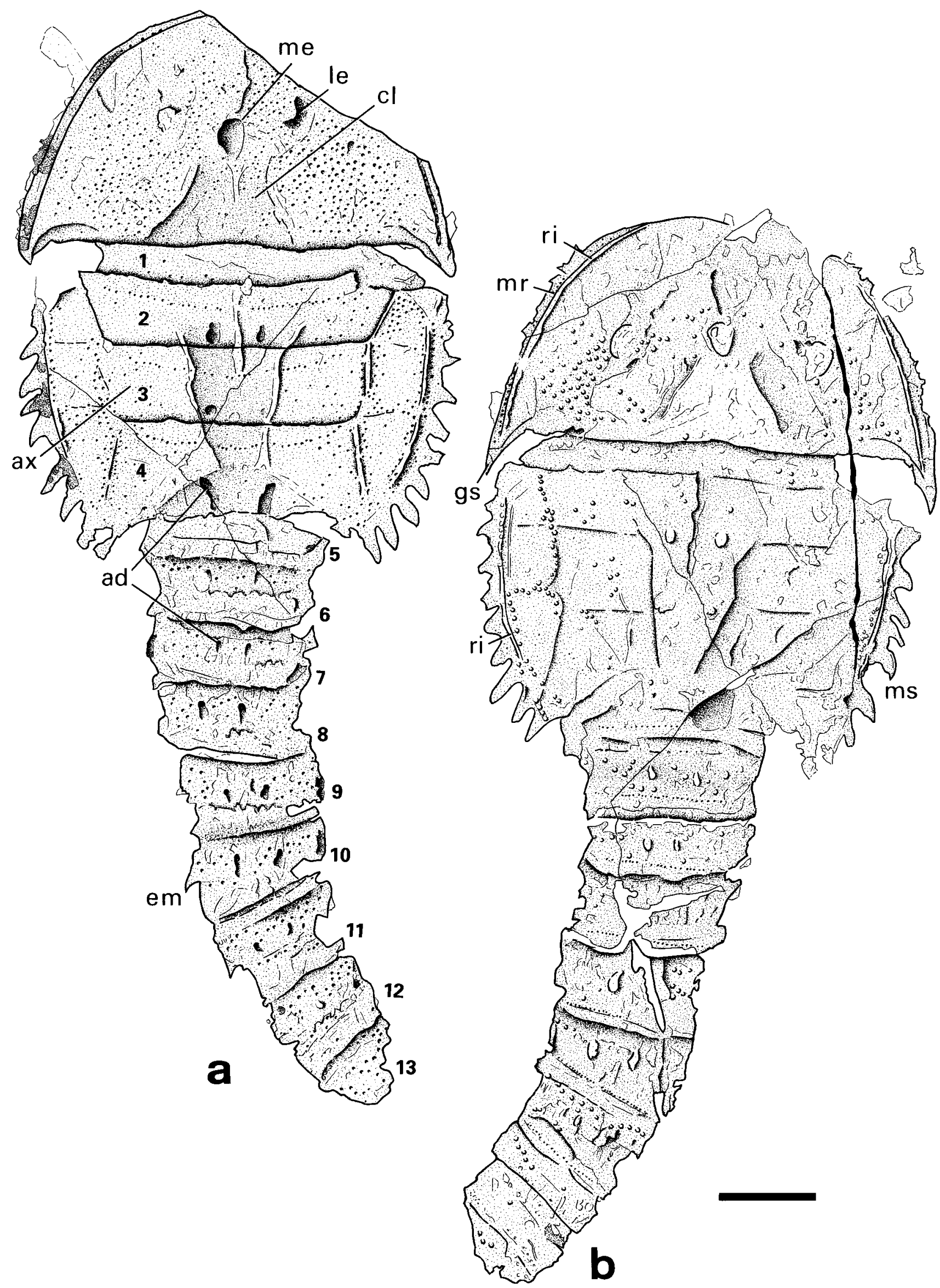

Figure 2 Camera lucida drawing of the specimens shown in Fig. 1. Scale bar $=5 \mathrm{~mm}$. 

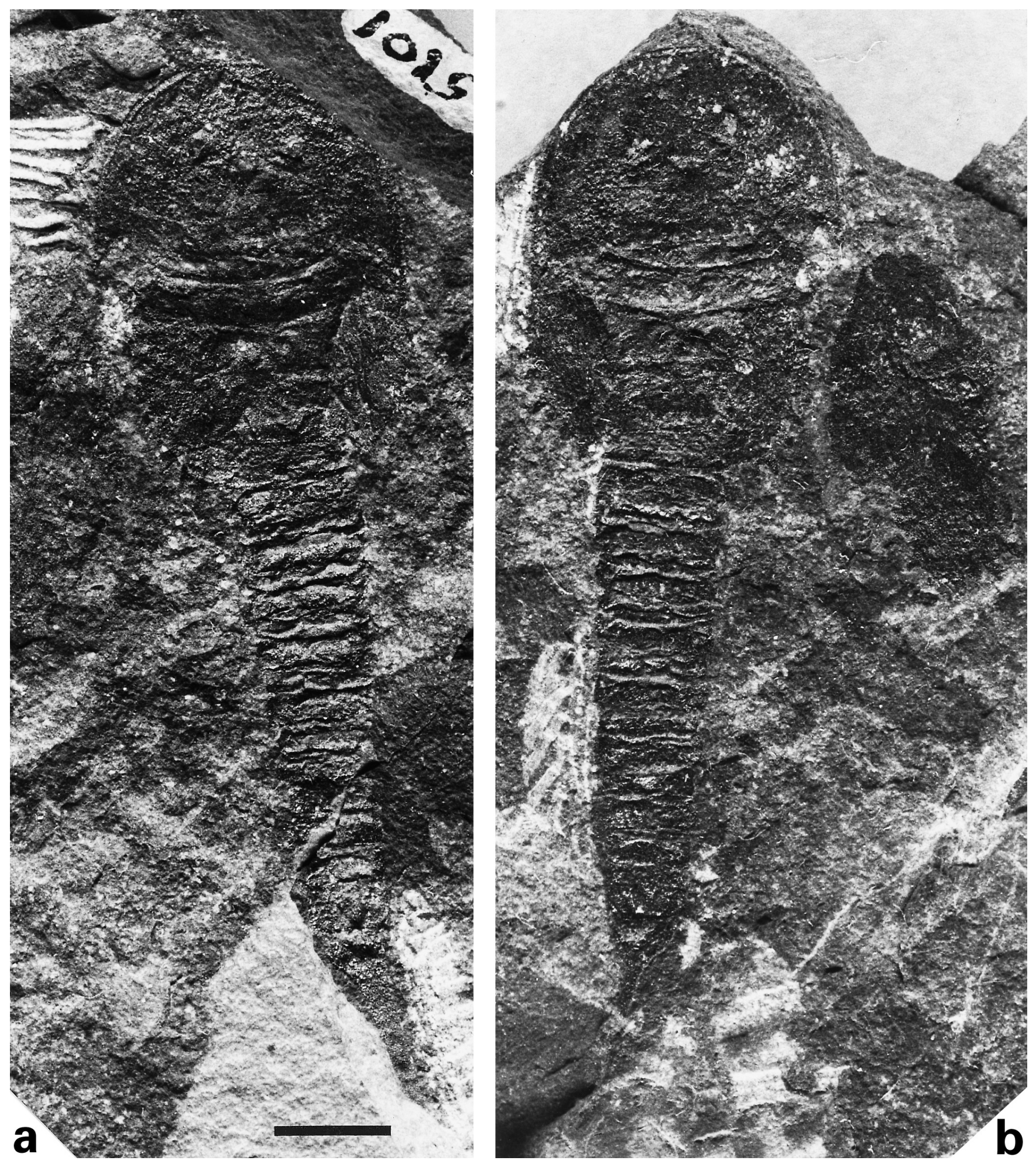

Figure 3 Chasmataspis laurencii Caster \& Brooks, 1956: USNM 125101 (paratype), from the same locality as the holotype, but preserved slightly differently in a darker matrix. An almost complete specimen in dorsal view: (a) part; (b) counterpart, also showing an associated, but apparently distorted ventral plate (see also Fig. 6). Scale bar $=5 \mathrm{~mm}$.

towards the edges of the shield and in a subtriangular area behind the median eye tubercle. This subtriangular region is slightly raised and is weakly delimited on its lateral sides. Caster \& Brooks (1956) designated this region the glabella, regarding it as equivalent to the cardiac lobe of xiphosurans, the term the present authors adopt here. Note that a similar, subtriangular cardiac lobe was also described by Selden (1981) in eurypterids. Bergström (1975) referred to a radiating pattern of tuberculation in C. laurencii. However, the present authors were unable to confirm the latter observation, and neither their drawings (Figs 2, 4), nor the reconstruction of Caster \& Brooks (1956) pick out radiating features. In synziphosurines, radiating features on the prosomal dorsal shield tend to indicate underlying morphological features associated with the prosomal appendages.

A relatively large pair of median eyes, or ocelli, are located on a slightly raised, heart-shaped ocular tubercle in the middle of the dorsal shield, immediately anterior to the cardiac lobe. Either side are a pair of oval to reniform lateral eye tubercles (Figs 1,2). These are flatter than the median eye tubercle and 

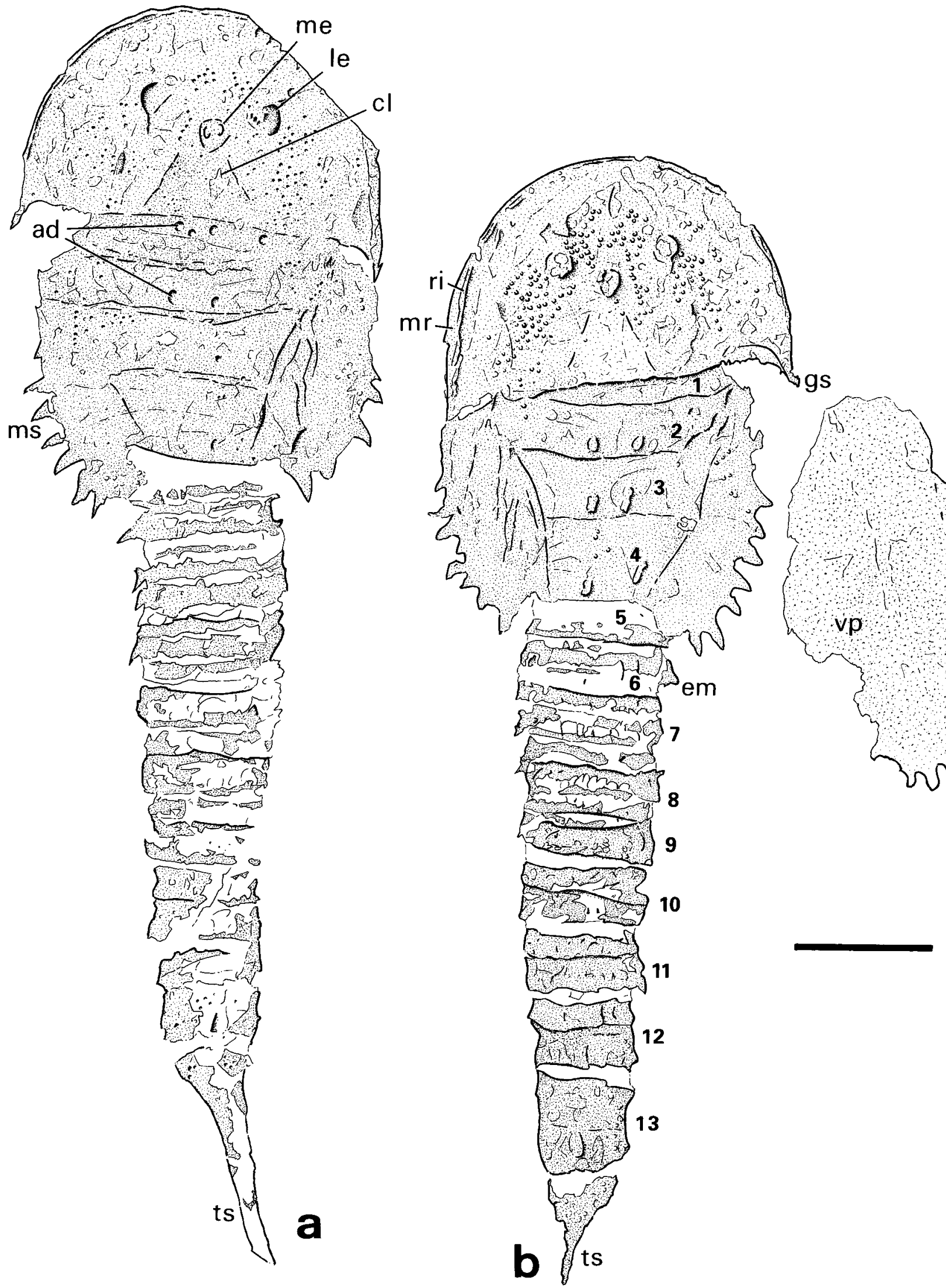

Figure 4 Camera lucida drawing of the specimens shown in Fig. 3. Scale bar $=5 \mathrm{~mm}$.

are not particularly distinct. Although resembling the compound eyes of extant xiphosurans in gross morphology, individual lenses cannot be determined on the lateral eye tubercles in these fossils. The lateral eyes of $C$. laurencii do not sit on any sort of ophthalmic ridge, a diagnostic characteristic for Xiphosura (see Anderson \& Selden 1997 for details). 

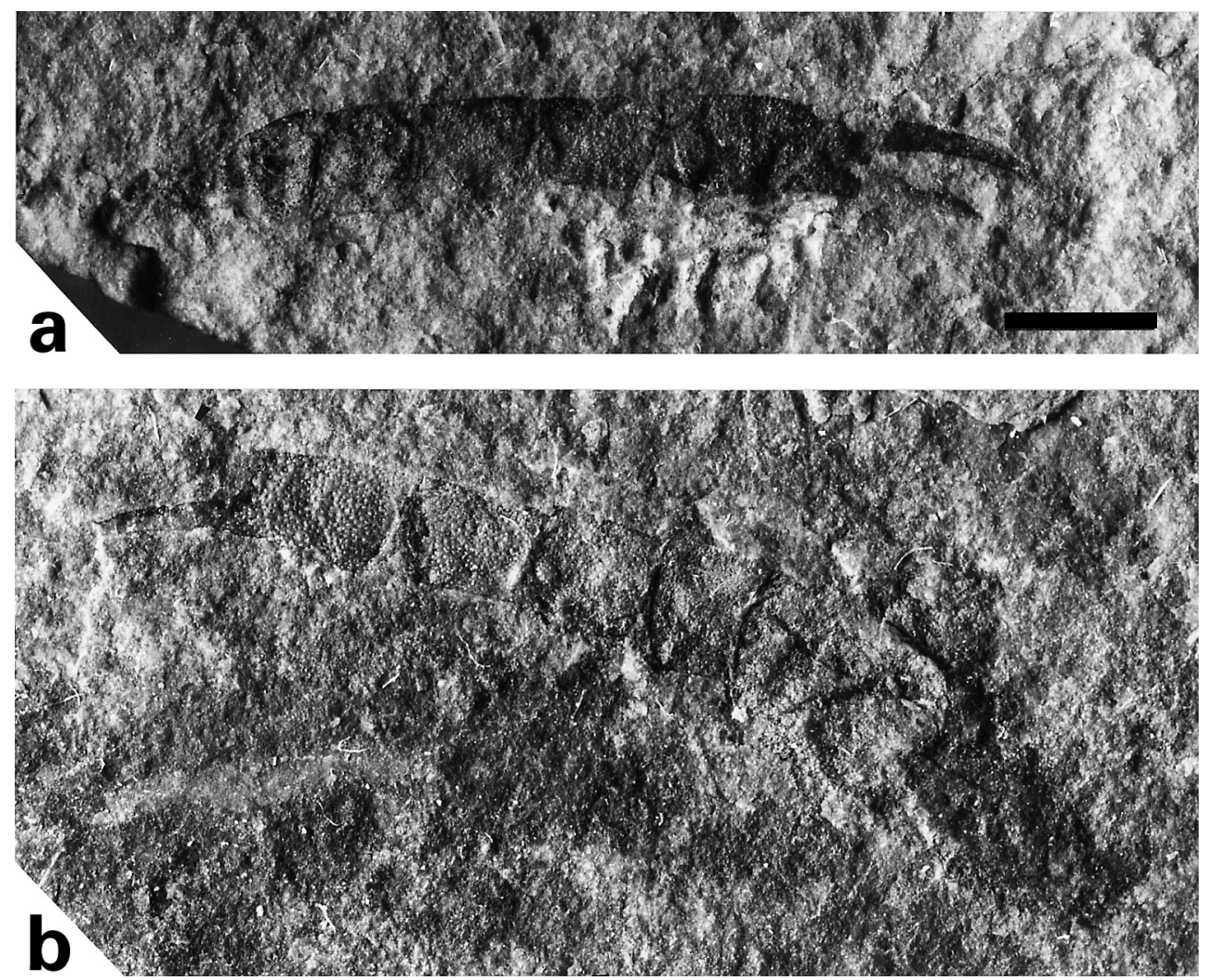

Figure 5 Chasmataspis laurencii appendages on slab USNM 125106 from the same locality as the holotype: (a) distal end of a leg showing terminal chelate claw; (b) almost complete limb showing basipod with a mesal gnathobase, and both an exopod and endopod ramus. Scale bar $=2 \mathrm{~mm}$.

\subsection{Prosomal appendages}

The ventral surface of the prosomal region is not preserved in C. laurencii, although it was reconstructed by Simonetta \& Delle Cave (1981) and Delle Cave \& Simonetta (1991) with a large, somewhat trilobite-like (but entirely hypothetical) hypostome and a distinctly xiphosuran-like arrangement of the limbs, with long, slender, gnathobasic legs. Caster \& Brooks (1956) described the appendages in C. laurencii based on three specimens, two of which occur on slab USNM 12506 and are illustrated here (Figs 5, 6). Unfortunately, both these almost complete appendages are disarticulated from the body. Since the only other arthropod known from this locality is the rare crustacean that has a body length similar to the length of these isolated limbs, and other disarticulates of chasmataspids occur within the sediments, it seems reasonable to interpret these appendages as belonging to the much large $C$. laurencii. It is impossible to say which appendage they represent - they have too many podomeres to be the chelicerae - or whether this morphology is typical for all prosomal legs, as implied by Simonetta \& Delle Cave's (1981) reconstruction. There is no evidence in $C$. laurencii for the modification of one of the appendage pairs into a paddle, as seen in Diploaspis and Octoberaspis, but since a complete limb series is lacking, the present authors cannot exclude the possibility that $C$. laurencii had paddles.

Like the body, the cuticle of the appendages has a microornament of pits, and most of Caster \& Brooks' (1956) observations on the leg of $C$. laurencii can be confirmed here. The ground pattern of the leg in Chelicerata may have comprised a double femur (see Shultz 1990 for a discussion). Rather than attempting to homologise the podomeres in these fossils with the traditional femur-patella-tibia scheme used in arachnids and xiphosurans, the present authors adopt the convention of Selden (1981) for eurypterids, and number the podomeres from proximal to distal, starting with the basipod as number 1 . The basipod (or coxa in more traditional terminologies) is subrectangular in C. laurencii, but widens distally and has a distinct dorsal curvature (Figs 5b, 6b). It has a surprisingly well-preserved mesal gnathobasic edge (best seen under alcohol) with at least five slightly upward-curving spines and, more ventrally, it bears a row of fine setae. This gnathobase is similar to that of both eurypterids and extant xiphosurans.

At least one of the limb pairs in C. laurencii was biramous and the basipod bears both an ill-defined exopod and a pediform endopod (Figs 5b, 6b). The exopod is, unfortunately, rather poorly preserved, but vaguely resembles the flabellum on prosomal limb VI of extant xiphosurans and the exopod on limb VI in the putative Silurian chelicerate Offacolus kingi Orr et al., 2000b (see section 6.1). In comparison to the limb types figured by Walossek \& Müller (1997), this exopod shows no evidence of having been composed of a series of podomeres or of having borne lamellar spines or setae. The endopod is composed of seven podomeres. Five of these (2-6) are relatively short, approximately as wide as long, and 2 and 3 have angled planes of articulation such that podomere 3 rises slightly and acts as a weak 'knee' joint, directing the more distal podomeres in a somewhat ventral direction (Figs 5b, 6b). Podomere 7 is noticeably longer, and the inferior distal region is drawn into the long, fixed finger of the claw. Podomere 8 is missing in one of these limbs, but in the other, it can be seen to form the free finger of the claw, and this gently curving and tapering element articulates in a superior position relative to the fixed finger (Figs 5a, 6a). In the preserved example, the free finger is slightly longer than the fixed finger.

The overall impression is of an animal with short, stubby limbs which were both proximally gnathobasic and distally chelate, and in which at least one limb pair remained 


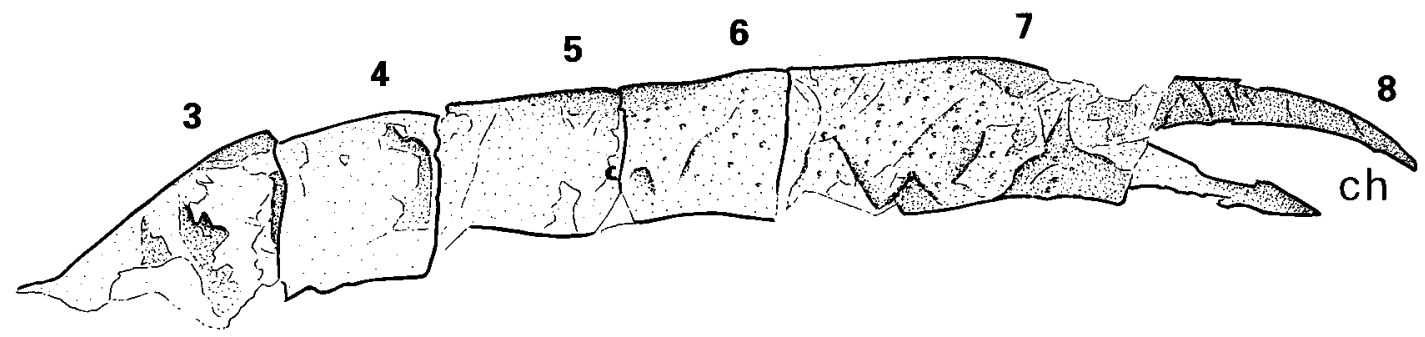

a

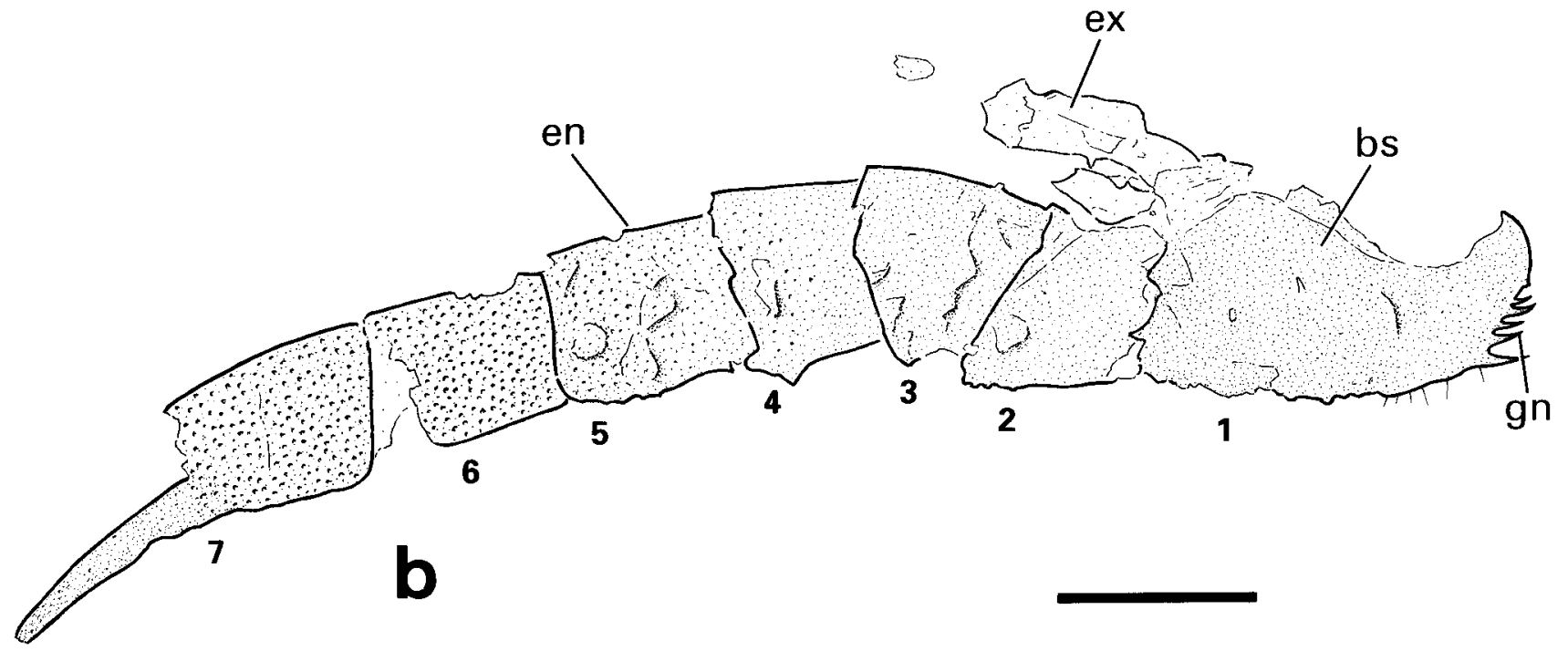

Figure 6 Camera lucida drawing of the specimens shown in Fig. 5. Podomeres numbered from (1) proximal to (8) distal. Scale bar $=2 \mathrm{~mm}$.

biramous. Although the present authors lack an entire limb series in situ, they suspect that these were held, xiphosuranlike, beneath the prosomal dorsal shield, and not as in the reconstruction of Simonetta \& Delle Cave (1981), in which the limbs projected markedly beyond this shield. This interpretation is also supported by the resting impressions described below (see section 5).

\subsection{Opisthosoma}

4.3.1. Tagmosis and tergite 1. Caster \& Brooks (1956) divided the opisthosoma into an anterior preabdomen and a posterior postabdomen, and their terminology is adopted here. These authors recognised 12 opisthosomal segments: three in the preabdomen and nine in the postabdomen. Subsequent authors (e.g. Selden \& Siveter 1987; Dunlop \& Selden 1997) have followed this interpretation, although Simonetta \& Delle Cave (1981) regarded the number of preabdominal segments as unknown, assuming it to be three, while Starabogatov (1990) suggested that there was an additional, pregenital segment fused to the prosomal dorsal shield.

Twelve opisthosomal segments have been widely interpreted as a ground pattern character for chelicerates (see section 6.3). However, even in their original description, Caster \& Brooks (1956) noted a smooth 'process' anterior to, but separated from, the preabdomen. They interpreted this as an articulation surface. The present authors' re-examination confirms the presence of this sclerotised element, the same colour as the other cuticular structures, which lies between the prosomal dorsal shield and the preabdomen (Figs 1-4). This structure is slightly narrower than the adjacent dorsal shield and preabdomen, and is lightly tuberculated like the rest of the cuticle. The present authors interpret this as a true body segment, the tergite of opisthosomal segment 1 , and not simply an articu- lating structure (cf. Caster \& Brooks 1956) and/or a pseudosegment derived either from the carapace or the preabdomen. In the paratype (USNM 125101), there appear to be a pair of muscle apodemes on this structure (Fig. 4), which supports the interpretation of this element as a true body segment. Tergite 1 in C. laurencii is short in comparison to the other tergites, although it remains quite broad and is not quite a microtergite sensu Anderson \& Selden (1997, char. 3). Indeed, there is some evidence that there was an epimera-like spine at each lateral margin (Fig. 2), rather like the fixed spines on the margins of the preabdomen.

4.3.2 Preabdomen. The preabdomen is a shield-shaped sclerite, formed from these fused tergites (2-4), which Caster \& Brooks (1956) called the buckler, plus the reduced tergite 1. Here tergite boundaries are still visible, but two features strongly suggest that the whole preabdominal buckler was a single, fused plate. First, when compared to the postabdomen, the tergite margins are only weakly demarcated and articulation between them appears to be impossible. Secondly and more significantly, the lateral margins of the whole preabdominal buckler form continuous borders (Caster \& Brooks' marginal girdle) which express no segmental division whatsoever (Figs 1-4). These margins are thrown into a series of fixed marginal spines. Tergites 2 and 3 are approximately the same length as each other, but tergite 4 is slightly longer. All three tergites in $C$. laurencii are divided into median and lateral plates, with the lateral plates being less than one-third of the width of the median ones. In other words, $C$. laurencii has a broad axial region in the pre-abdomen, a characteristic that distinguishes it from the Devonian chasmataspids (see section 7). Interestingly, the holotype has a somewhat ill-defined median band (Figs $1 \& 2$ ) within the broad axial region, which could conceivably be a further axial structure or even the true 
axis, similar to the narrow axis in some fossil xiphosurans. The difficulty with this hypothesis is its slight asymmetry and its apparent absence in the paratype (Figs 2, 3), and thus, the present authors leave the interpretation of this enigmatic structure open.

All three preabdominal buckler tergites (2-4) have a pair of relatively large, oval tubercles located close to the midline (Figs 1-4). These are interpreted as tergal muscle apodemes. Like the prosomal dorsal shield, the preabdomen has a tuberculate ornament. These tubercles tend to form lineations which, at least laterally, closely follow, and help to define, the boundaries between the axial and lateral regions of the tergites (Figs 1,2). The lineations of tubercles also extend across the axial region itself, but here the line curves posteriorly, behind the tergite boundary. The segmented area of the buckler is bordered laterally by a narrow ridge, similar to that defining the carapace rim, and in overview, these carapace preabdomen ridges are almost continuous with each other, outlining the front half of the animal. Outside this ridge is a wide marginal region of the preabdomen which lacks external segmentation. On each side, this margin is thrown into a series of at least nine fixed, immobile and blunt spines which give the edges of the preabdomen a strongly serrated appearance. The tuberculation continues onto this marginal region.

4.3.3. The ventral buckler. Caster \& Brooks (1956) also described a second type of buckler, a thin, chitinous structure that lacked strong segmental divisions (Figs 4b, 7). This structure has the same basic shape as the buckler described above, including the marginal serrations, but the anterior margin is distinctly procurved in the middle and the posterior margin is also strongly procurved. Caster \& Brooks (1956) interpreted this structure as the ventral surface of the preabdomen, and figure material in which both the dorsal and ventral sclerites are apparently preserved in situ, one on top of the other (Caster \& Brooks 1956, pls 17, 19). They also observed what they interpreted to be a pair of anterior, slit-like openings in the ventral buckler and the impressions on the buckler of a pair of large chambers (of unspecified function) within the preabdomen. The present authors could not confirm this observation in the material they saw, but Caster \& Brooks (1956) felt that these narrow slits were more likely to be openings to the genitalia, as opposed to the respiratory organs.

Størmer (1972) identified a similar ventral plate in the Devonian Alken material and regarded this structure as diagnostic for Chasmataspidida. At least in Diploaspis, Størmer (1972) interpreted this ventral plate as protecting the gills, perhaps as an adaptation to prevent desiccation during occasional activity on land. In Størmer's (1972) model, the ventral plate attached along its anterior margin - rather like a single, huge operculum - and opened to the environment posteriorly. Simonetta \& Delle Cave (1981) interpreted the respiratory organs of $C$. laurencii rather differently. To them, the preabdominal chambers described by Caster \& Brooks (1956) were respiratory cavities which opened via the anterior slits in the ventral buckler. Simonetta \& Delle Cave (1981) noted the obvious problems with such a closed system in an aquatic environment and hypothesised some sort of elaborate pumping mechanism associated with the respiratory chambers, a strange system quite unlike anything known from other chelicerates. These authors also noted that a closed system with slit-like openings could be adapted to life in air and suggested that, despite its age, $C$. laurencii could have been partially terrestrial, feeding as a scavenger on the strand line.

Dunlop (2002a) also identified this curious ventral plate in Octoberaspis, although here it was located between the dorsal preabdomen and a series of three ventral opercula, which can

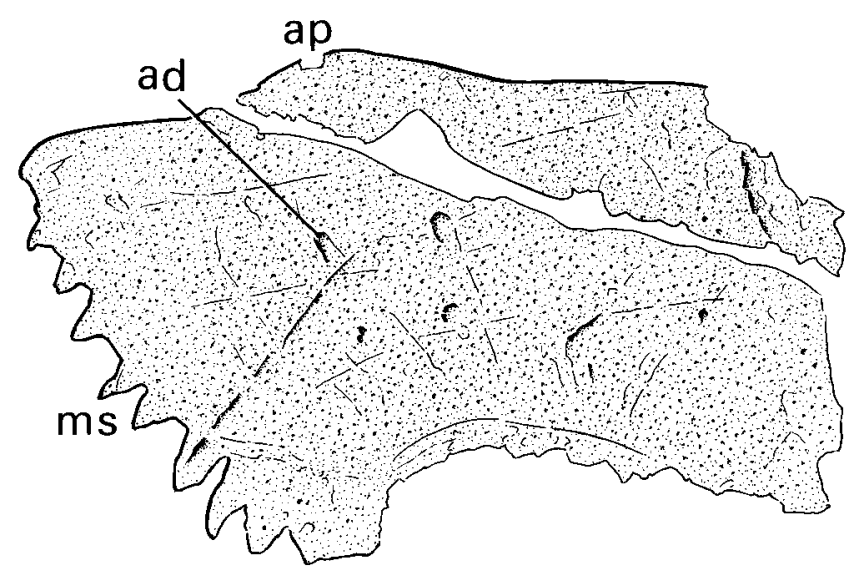

Figure 7 Camera lucida drawing of the enigmatic ventral plate in $C$. laurencii in USNM 125100 from the same locality as the holotype. Note the pitted surface, the slight anterior projection and the serrated lateral margin. Scale bar $=2 \mathrm{~mm}$.

clearly be seen in the Russian specimens in ventral view. Based on this, Dunlop (2002a) suggested that the ventral buckler of all chasmataspids may be equivalent to the weakly sclerotised region which forms a strongly indented, arched plate overlying the gills in extant xiphosurans, thus forming the roof of the branchial chamber. Shultz (2001) referred to this area in extant xiphosurans as 'pliable cuticle', lying in front of a harder postopercular plate. Applying this to $C$. laurencii, one possible interpretation of the ventral buckler is that it may not be the true ventral surface of the preabdomen, but rather a sclerotised area which lay above a series of (?gill-bearing) opercula, similar to those of Limulus. The Hickory Sandstone traces (see section 5) also imply the presence of preabdominal opercula in a Chasmataspis-like animal and suggest a more typical respiratory system for an aquatic euchelicerate with a series of plate-like opisthosomal appendages.

However, there is a problem with the present authors' interpretation of the ventral buckler of $C$. laurencii. It lacks the deeply incurving space seen in the pliable cuticle above the gills of Limulus (JAD pers. obs.), a space in which the six opercula attach to the body. In C. laurencii, the ventral buckler forms a single plate without breaks or a large, anterior indentation (Figs 4b, 7), and it is unclear where the chasmataspid opercula would have attached in this model. Therefore, they are unable to resolve the exact life position and function of this enigmatic ventral buckler in $C$. laurencii, and cannot exclude the possibility that it was a true ventral plate which is autapomorphic for the species. Nevertheless, the authors find an opercularbased model of ventral appendages (see section 5) more convincing than the hypotheses of Størmer (1972) and Simonetta \& Delle Cave (1981).

4.3.4. Postabdomen. The postabdomen of C. laurencii is an elongate structure consisting of nine, apparently ring-like segments (Caster \& Brooks 1956). The postabdomen shows a strong degree of tagmosis from the preabdomen (Figs 1-4). The postabdominal segments become slightly narrower posteriorly, but do not show the more abrupt tapering typical of the Devonian chasmataspids (see section 7) in which the postabdominal segments are sometimes preserved telescoped into one another (Dunlop 2002a). In a number of cases (e.g. USNM 125099), the postabdomen is preserved bent to one side, which implies that it was mobile in life. However, there are no special modifications of the articulations between the postabdominal segments as occur in the extremely mobile postabdomen of scorpions. 
The individual postabdominal segments in C. laurencii are more or less rectangular in dorsal view with straight posterior and lateral margins, and an ornament of tubercles similar to those on the carapace and preabdomen. These postabdominal tubercles do not form any particular pattern, but tend to be concentrated in a band across the middle of the segment rather than at the anterior or posterior margins. The first five postabdominal segments have pairs of larger, elongate tubercles, orientated anteroposteriorly, and relatively close to each other near the centre of the segment. As with the preabdomen, these probably represent muscle apodemes. They were not clearly shown in Caster \& Brooks' (1956) reconstruction, which implied two pairs of indistinct apodemes per segment. Only one pair was observed in this study. Caster \& Brooks (1956) reconstructed each postabdominal segment with triangular epimera on each lateral margin. Small, but generally rather poorly-preserved, epimera can be seen on a few postabdominal segments (Figs 2, 4).

The telson in C. laurencii is lanceolate and ends in a bluntly pointed tip (Figs 3, 4). It joins onto the postabdomen with a broad base. This relatively long telson is diagnostic for Chasmataspididae (see section 7).

\section{Chasmataspis-like traces}

Several arthropod resting traces (Figs 9, 10) preserved in hyporelief on the base of a fine-grained, cross-bedded sandstone slab (indicating a shoreline to estuarine setting) are known from the Hickory Sandstone Member of the Riley Formation (Upper Cambrian: Dresbachian) of Texas, USA. The slab includes three detailed examples, possibly resulting from the same individual repositioning itself. These traces, attributed to 'merostomes' by Wahlman \& Caster (1978), reveal the ventral anatomy of the producer. This was a c. 55-mm-long animal with a horseshoe-shaped prosoma bearing imprints of at least five pairs of prosomal appendages which barely appear to reach the prosomal margin and which increase in length posteriorly. The producer also had a somewhat subtrapezoidal preabdomen and a long, slender postabdomen ending in a lanceolate telson. Of particular interest are the imprints of five or six pairs of elongate, overlapping opercula which decrease in length posteriorly (Figs 9, 10). These opercular impressions conceivably represent three larger preabdominal opercula, and two or three smaller opercula at the anterior end of the postabdomen.

The overall size and shape of these impressions is remarkably consistent with the known morphology of Chasmataspis laurencii, although the Hickory Sandstone fossils are derived from a much older (ca. 40 Ma older) formation. This ichnological data is significant since, if our assignment to Chasmataspidida is correct, it potentially extends the fossil record of chasmataspids (and thus all Euchelicerata) back to the Upper Cambrian. Waloszek \& Dunlop (2002) reviewed Cambrian records of Chelicerata and suggested that their larval pycnogonid from the Upper Cambrian 'Orsten' of Sweden is the oldest unequivocal record of Chelicerata. Anderson \& Selden (1997) excluded a number of unreliable Cambrian 'horseshoe crabs' from Xiphosura. Other reports of early chelicerates such as the famous Middle Cambrian Sanctacaris from the Burgess Shale of Canada or the Lower Cambrian aglaspidid-like Kodymirus from the Paseky Shale of the Czech Republic-the latter assigned to Eurypterida by Chlupáč (1995)-do not preserve autapomorphies of Chelicerata such as chelate chelicerae.

The Hickory Sandstone material does not preserve chelicerae either, but the impressions of plate-like opisthosomal opercula (Figs 9, 10) strongly imply that these fossils should be referred specifically to Euchelicerata, since these opercula are one of the apomorphic features used by Weygoldt \& Paulus (1979, char. 10) in their original definition of the euchelicerate clade. These structures also support the present authors' interpretation of the respiratory system in C. laurencii (see section 4.2.3), since they imply an animal with a ventral anatomy more like that of other aquatic chelicerates. These trace fossils could also indicate that chasmataspids occupied tidal flat facies. A formal description of this material is currently in preparation (G. Wahlman, pers. comm., 2001).

\section{Discussion}

Chasmataspis laurencii is one of the oldest known chelicerates and is of particular interest for understanding basal relationships in the Euchelicerata, since it exhibits a number of characters which are typical for Xiphosura, for example: (1) the horseshoe-shaped prosomal dorsal shield; (2) the cardiac lobe; (3) well-developed genal spines; (4) prosomal appendages which are biramous and/or have endopods terminating in a chelate claw; (5) a preabdomen in which the segments are fused together into a dorsal shield; and (6) a preabdominal axial region. Note that characters 3,4 and 5 are specific autapomorphies of the Carboniferous-Recent crown-group Xiphosurida while biramous appendages are also present in the Silurian fossil Offacolus kingi.

By contrast, the Devonian chasmataspids (Diploaspididae) are rather more eurypterid-like, and lack both a clearly defined cardiac lobe and the strongly fused preabdomen with an axial region, and have only tiny genal spines. Diploaspis preserves a limb with marginal spines on the distal podomeres that ends in a blunt pretarsus (Størmer 1972; Dunlop et al. 2001). This morphology essentially matches the Hughmilleria-type limb in Tollerton's (1989) eurypterid classification. Furthermore, Octoberaspis preserves a distinct genital appendage and a metastoma (a plate covering the posterior gnathobases) (Dunlop 2002a), both traditionally diagnostic characteristics of Eurypterida. Tetlie \& Braddy (2004) also described a genital appendage and metastoma in their Silurian chamataspid. This pattern of character distribution could support the polyphyletic hypothesis, i.e. (Chasmataspis +Xiphosura) and Diploaspididae + Eurypterida).

\subsection{Support for chasmataspid monophyly}

Chasmataspid monophyly is supported by one very good synapomorphy (Dunlop \& Selden 1997); the tagmosis of the opisthosoma with a short segment 1, a three-segmented preabdominal buckler and a nine-segmented postabdomen (Figs 1-4). Other euchelicerates also show preabdomenpostabdomen tagmosis, but the postabdomen consists of five segments in scorpions and eurypterids (e.g. Dunlop \& Webster 1999), three segments in synziphosurines (e.g. Anderson \& Selden 1997) and three in some arachnids (cf. Shultz's (1990) apomorphic 'pygidium' character). Tagmosis has also been reported in the Silurian fossil Offacolus kingi from Herefordshire, England, an intriguing animal with a rather short trunk, but one which, according to Orr et al. (2000b), also appears to be a chelicerate. Polarising this tagmosis character for Euchelicerata is difficult and the postabdomens of arachnids (segments 10-12) and xiphosurans (segments 8-10?) appear not to be sequentially homologous.

Among potential outgroups, those Devonian pycnogonids which retain a longer, post-appendicular trunk lack a clear pattern of tagmosis (Bergström et al. 1980). Alternatively, among potential arachnate outgroups, there are taxa both with 


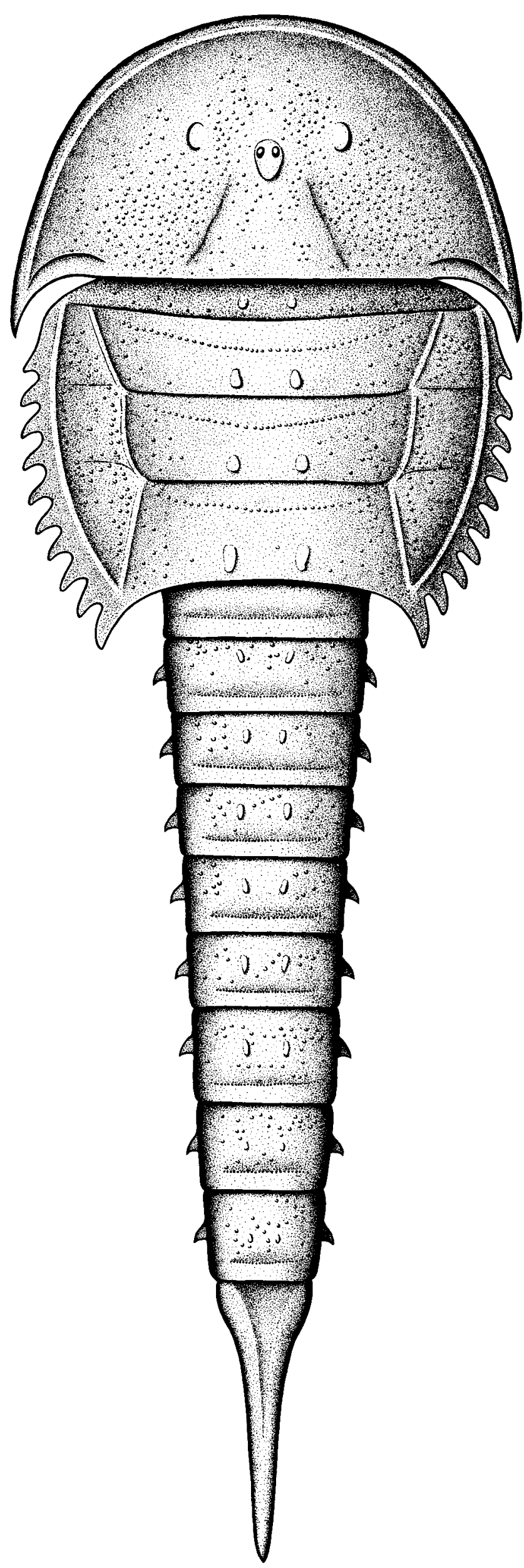

Figure 8 Suggested reconstruction of C. laurencii in dorsal view based on a composite of the available material. 
(e.g. Emeraldella and Sidneya) and without (e.g. Paleomerus, Strabops and Cheloniellon) some degree of tagmosis at the posterior end of the body. Although there have been moves towards resolving arachnate relationships (Hou \& Bergström 1997; Edgecombe \& Ramsköld 1999), there is still no clear phylogeny for the stem-group leading up to Chelicerata, and thus, the present authors cannot assess whether posterior trunk tagmosis is likely to have been part of the ground pattern for the chelicerate clade. With the intriguing exception of the Chengjiang fossil Fuxianhuia, elongate postabdomen-like tagma are generally not seen in early Palaeozoic arthropods and the plesiomorphic condition for Euarthropoda has been reconstructed as a series of unmodified trunk segments (e.g. Walossek \& Müller 1997, fig. 12.8).

The present authors suggest that the $3+9$ tagmosis should be interpreted as a potential synapomorphy for (Chasmataspis + Diploaspididae). It is interesting to note that $O$. king $i$ has been described as having a preabdomen with three (unfused) segments like chasmataspids, plus a postabdomen of five fused segments (Orr et al. 2000b). In general, it is difficult to envisage the tagmosis pattern in $C$. laurencii giving rise to that seen in xiphosurans, eurypterids or arachnids without significant reversals in the structure of the preabdomen and its associated respiratory organs. Furthermore, when examined in detail, the case for (Chasmataspis +Xiphosura), to the exclusion of Diploaspididae, looks less convincing since different polarity decisions can be reached by selecting alternative outgroup taxa.

6.1.1. Prosomal dorsal shield characters. The horseshoeshape of the prosomal dorsal shield (character 1) is an unreliable synapomorphy for (Chasmataspis + Xiphosura) since it also occurs in hughmillerid eurypterids (e.g. Tollerton 1989, fig. 2) and various outgroup arachnate genera (e.g. see figures in Simonetta \& Delle Cave 1981 and Hou \& Bergström 1997). The cardiac lobe (character 2) is a stronger potential synapomorphy for (Chasmataspis + Xiphosura), although, as noted above (section 4.1.), it has also been reported in some eurypterids. Caster \& Brooks (1956) implied homology of the cardiac lobe with the trilobite glabella, but since the segmental composition of the trilobite cephalon is different to that of the xiphosuran prosoma, this interpretation is questionable. Nevertheless, notwithstanding problems relating to assessing raised structures in compressed material, a number of arachnates show some degree of swelling on the head shield in the 'glabellar' region. In the absence of a stem line for Chelicerata (see section 6.1), the polarity of this character in C. laurencii remains unclear. Genal spines (character 3 ) can technically be scored as present in the entire Chasmataspidida clade, they are simply smaller in Diploaspis and Octoberaspis, and equivocal in the less well preserved Forfarella and Achanarraspis.

Bergström (1975) used the marginal rim of the prosomal dorsal shield (see section 4.1) to include $C$. laurencii among the xiphosurans, as opposed to the eurypterids, although a similar rim is clearly present in many eurypterid taxa (e.g. see Størmer 1955, fig. 17A). The supposedly serrated margin of the head shield in C. laurencii (see section 4.1) was cited by Bergström (1975) as evidence that this animal was related to the synziphosurines, but even within this group, the serrate margin (Anderson \& Selden 1997, char. 18) is an autapomorphy restricted to the genus Limuloides. The pustulate ornament of the prosomal dorsal shield in C. laurencii was also suggested by Bergström (1975) as more xiphosuran-like than the scalar ornament typical for eurypterid cuticle. However, pustulate ornament is seen in various disparate eurypterid taxa (e.g. Carcinosoma and Buffalopterus; c.f. Kjellesvig-Waering \& Heubusch 1962), or Drepanopterus and Rhenopterus.

6.1.2. Prosomal appendages. The chelate appendage (character 4) in C. laurencii appears to be a good synapomorphy shared with Xiphosura, and is similar to the distal chelae in the legs of both living xiphosurans and well-preserved Carboniferous forms (Schultka 2000; Racheboeuf et al. 2002). The absence of chelae in the Diploaspis leg was the principal reason why Bergström (1975) excluded these fossils from Xiphosura. However, in their redescription of the synziphosurine Weinbergina, Stürmer \& Bergström (1981, figs. 1-3, 7) illustrated well-preserved legs ending in a trifurcate structure, and not an opposable, chelate claw. This trifurcate morphology could even be the ground pattern character state for Chelicerata (see Dunlop 2002c for a discussion). Weinbergina implies that chelate postcheliceral appendages may have evolved within the Xiphosura clade, and it is worth noting that limbs II and III are only subchelate in the extant horseshoe crab Tachypleus tridentatus (JAD pers. obs.).

As pointed out by both Eldredge (1974) and Dunlop et al. (2001), the paddles preserved in Diploaspis and Octoberaspis are a poor synapomorphy to unite these taxa with Eurypterida, since not all eurypterids, or chasmataspids, have paddles. The enigmatic exopod retained on a leg in C. laurencii is clearly an expression of a plesiomorphic character state (e.g. see Walossek \& Müller 1997, fig. 12.9) for the ground pattern of the euarthropod limb. However, it does crudely resemble the flabellum on limb VI of Recent xiphosurans and reduction of the exopod to a flabellum-like element could support grouping C. laurencii with the Xiphosura. Nevertheless, this is clearly part of a general reductive trend in chelicerates to lose the exopod from the prosomal appendages and, thus, may represent a grade of organisation rather than an explicit synapomorphy of these taxa. The presence or absence of an exopod is equivocal in the Diploaspididae.

6.1.3. Preabdominal characters. The fusion of the preabdominal tergites (character 5) in C. laurencii is similar to the development of the thoracetron, or tergum (Shultz 2001), an autapomorphy of the Xiphosurida crown-group (Anderson \& Selden 1997, char. 20; Giribet et al. 2002, char. 114). The buckler of $C$. laurencii is considerably shorter than the thoracetron, and since the latter is an ingroup xiphosuran character, these developments are implicitly homoplastic. Anderson \& Selden (1997) discussed the possible advantages of fusion, in particular with respect to enrolment. The present authors have no evidence that $C$. laurencii enrolled, i.e. none of the fossils are preserved actually demonstrating this behaviour. Although the prosoma and preabdomen are similar in size and shape, and theoretically, could have occluded together (with the long postabdomen projecting), C. laurencii lacks either the microtergite (a tiny tergite 1) or the loss of this element as in Limulus (e.g. see Shultz 2001), which may be an integral aspect of the hinge mechanism allowing this behaviour in derived horseshoe crabs. In $C$. laurencii, tergite 1 remains relatively broad. That said, the synziphosurines Kasibelinurus and Legrandella both demonstrate capacity for loose enrolment involving articulated, but unfused opisthosomal segments.

An axial trunk region (character 6) appears to have arisen often - and almost randomly - throughout the Euarthropoda. For example, it was not scored in the arachnate analysis of Edgecombe \& Ramsköld (1999) and generally appears to be a character of uncertain polarity for arthropods, which complicates, rather than resolves, higher taxon relationships (G. Edgecombe, pers. comm., 2000). Within chelicerates it occurs in, for example, xiphosurans, mixopterid eurypterids, and both trigonotarbid and ricinuleid arachnids. Polarising this character for Euchelicerata is extremely difficult since it occurs in some potential outgroups (e.g. trilobites, Cheloniellion), but not others (e.g. Paleomerus, Sidneya and Emeraldella). 


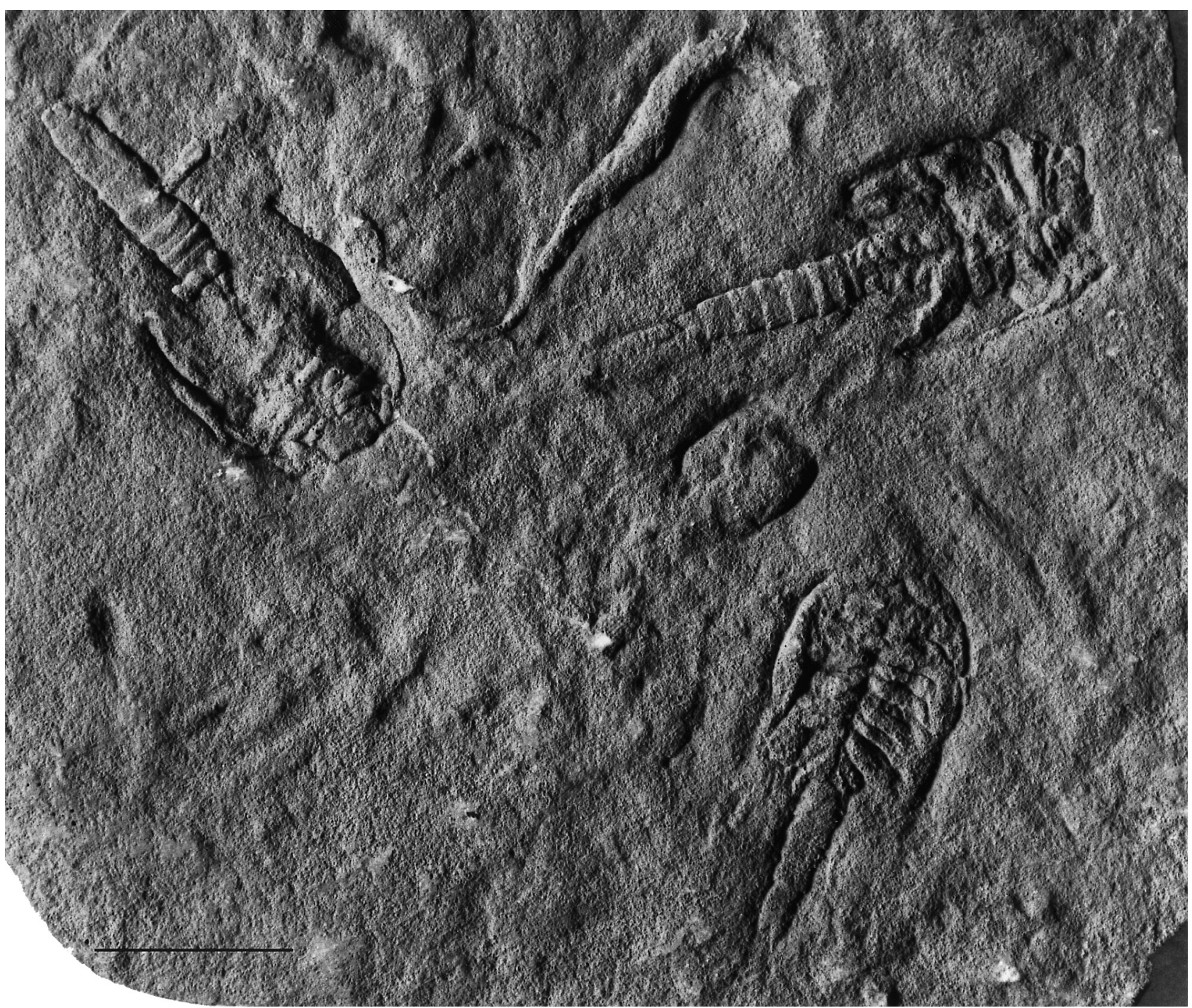

Figure 9 Cast of arthropod resting impressions from the Upper Cambrian (Dresbachian) Hickory Sandstone of Texas, USA, noted by Wahlman \& Caster (1978) as possible merostomes. The present authors suggest that the producer may have been a Chasmataspis-like animal with ventral opisthosomal opercula. Cast made at the University of Cincinnati, USA, and deposited in the palaeontology collections of the Museum für Naturkunde, Berlin, Germany (MBA 1084). Scale bar $=20 \mathrm{~mm}$.

\subsection{Affinities of Chasmataspis}

Chasmataspid monophyly is supported by their characteristic pattern of tagmosis, but the present authors cannot exclude the possibility that this character is homoplastic, or that we are dealing with some sort of poorly defined group of stemeuchelicerates in which some taxa are closer to the origins of Xiphosura and others to the origins of Eurypterida (see also Tetlie \& Braddy 2004). This can only be tested by integrating the two most complete examples, the xiphosuran-like Chasmataspis and the eurypterid-like Octoberaspis, into a detailed analysis of euchelicerate relationships. Attempting this here would be premature. Although we now have a broad framework for evolution within Xiphosura (Anderson \& Selden 1997), many aspects of chelicerate and/or arachnid relationships remain unresolved and controversial, especially with respect to the basal parts of the tree (Dunlop \& Braddy 2001; Giribet et al. 2002). Even the monophyly of Arachnida is contentious, but see Shultz (2001) for a recent defence. Relatively little has been published on eurypterid phylogeny and their monophyly has also been questioned (Tollerton 1989).

The genital appendage and metastoma described by Dunlop (2002a) for Octoberaspis are convincing synapomorphies shared with Eurypterida and might even support reassigning
Octoberaspis to the eurypterid clade. However, while the ventral surface of Chasmataspis remains poorly known, these two characters must be regarded as equivocal in this older taxon. Their presence would support (Chasmataspidida+ Eurypterida), while their absence would undermine the monophyly of the chasmataspids. A genital appendage and metastoma cannot be detected in the ventral impressions of the Chasmataspis-like Hickory Sandstone material, although the preservation here is imperfect. Affinities aside, Chasmataspis is significant in that it implies a radiation of the euchelicerates by the Mid-Ordovician, and perhaps even the Late Cambrian (see section 5). The present authors interpret a number of its xiphosuran-like features (i.e. genal spines, chelate limbs and fused preabdomen) as perhaps foreshadowing convergent developments in the crown-group horseshoe crabs which, despite their reputation as a classic example of 'living fossils', seem to have appeared in a modern form no earlier than the Lower Carboniferous.

\subsection{Thirteen opisthosomal segments}

The presence of 13 opisthosomal segments in chasmataspids is significant, since there is some debate in the literature about 


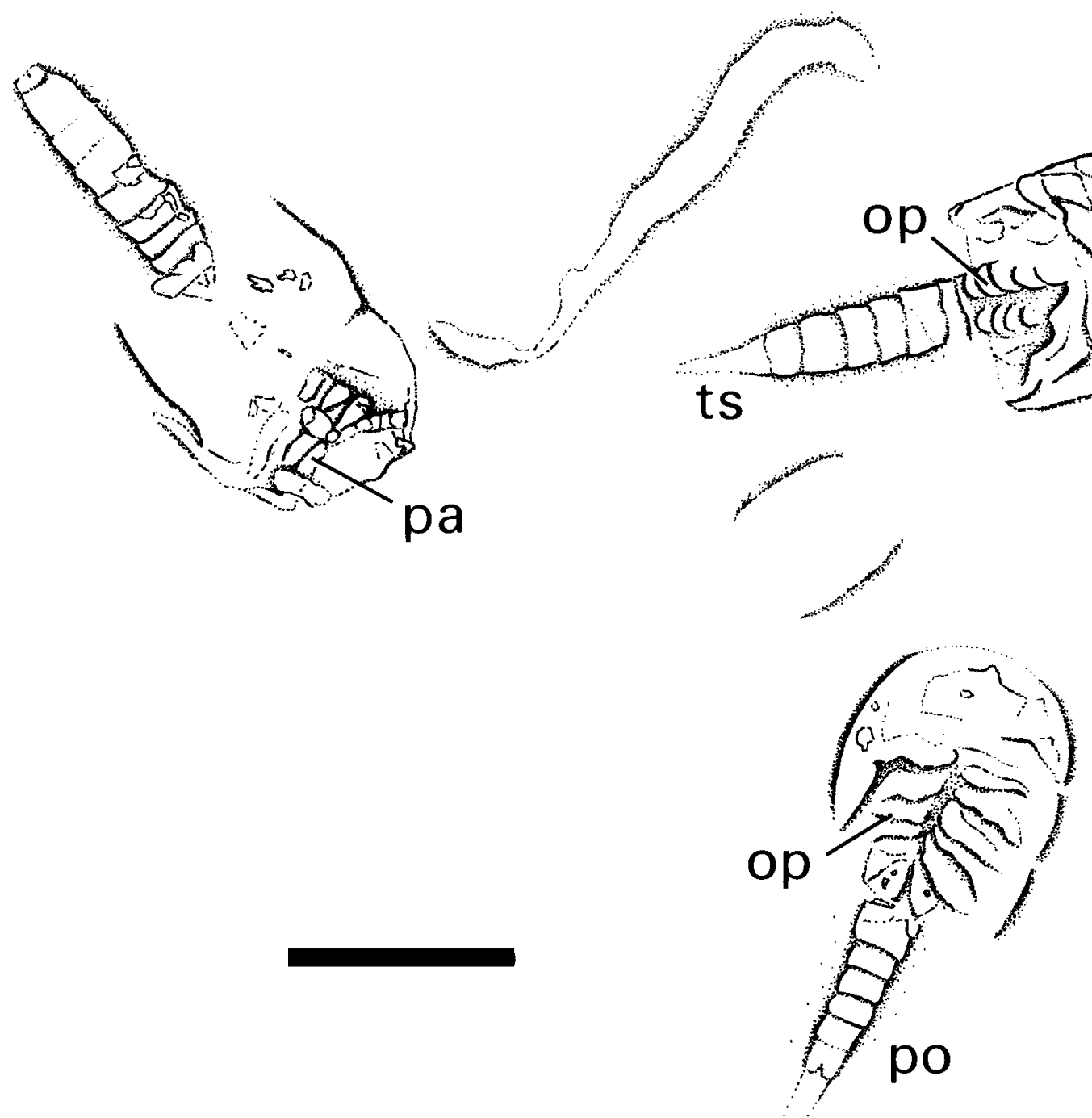

Figure 10 Interpretative drawing of the specimens shown in Fig. 9. Scale bar $=20 \mathrm{~mm}$.

whether Euchelicerata and/or Arachnida have a ground pattern of 12 (Størmer 1955; Savory 1971; Shultz 1990, fig. 3) or 13 opisthosomal segments (Millot 1949, figs 52, 53; Kraus 1976, fig. 7; van der Hammen 1989). Among living taxa, the problem group are the scorpions. A simple count reveals 12 segments, but it has long been recognised that there is an additional, but transitory, pregenital segment that appears as ventral limb buds during scorpion embryology (e.g. Brauer 1894). This ephemeral segment has been used to argue that the ground pattern in scorpions is 13 . However, other authors have accepted the embryological evidence, but invoked the secondary division of a segment near the base of the postabdomen (Buxton 1917; Petrunkevitch 1922) or a division of ventral elements in the genital region such that the gonopore and pectines effectively belong to the same segment (Weygoldt \& Paulus 1979, fig. 2). Both schemes return scorpions to a ground pattern of 12 .

Fossil scorpions complicate the picture since at least some forms had five ventral opercula instead of the four, appendagederived, book lungs seen in living taxa. At least one eurypterid has been shown, like extant scorpions, to have four pairs of lamellate respiratory organs (Braddy et al. 1999). Early stemgroup scorpions appear to have had more opisthosomal appendages than Recent ones, and the loss of one of these appendage pairs defines a clade within the latest scorpion tree (Jeram 1998, fig. 2, node F). There is also evidence for a reduced pregenital segment in eurypterids (Raw 1957; Dunlop \& Webster 1999), retained dorsally in at least one wellpreserved species as a thin, sclerotised element in the membrane between the prosoma and opisthosoma. This would bring the eurypterid opisthosomal segment number up to 13 and not 12, as has been traditionally assumed (e.g. Størmer 1955).

The significance of $C$. laurencii is that it is a euchelicerate which unequivocally preserves 13 opisthosomal segments (see section 4.3.1), and the same maximum number for Euchelicerata can also be observed in the well-preserved Octoberaspis from Russia (Dunlop 2002a). However, the polarity of this character is difficult to assess without a clear stem-lineage to provide taxa for outgroup comparison. It is tempting to interpret the longest known euchelicerate opisthosomas (13 segments) as plesiomorphic, with reductions in the number of trunk segments as alternative apomorphic states; for example 10 to 12 in most arachnids, 11 in basal xiphosurans, nine in derived xiphosurans, five in ticks and the vestigial trunk behind the walking legs in extant pycnogonids. Walossek \& Müller (1997) noted a high degree of plasticity in segment numbers among crustaceans, and since heterochronic changes during arthropod development can easily produce both longer and shorter body tagma, the relevance of these 13 segments in chasmataspids for euchelicerate phylogeny remains elusive. 


\section{Systematic palaeontology}

\author{
Chelicerata Heymons, 1901 \\ Euchelicerata Weygoldt \& Paulus, 1979 \\ Order Chasmataspidida Caster \& Brooks, 1956
}

Emended diagnosis. Euchelicerata retaining opisthosomal segment 1 as a short, broad sclerite, followed by a distinctive tagmosis into a three-segmented preabdomen (segments 2-4) and a narrower, nine-segmented postabdomen (segments 5-13). Emended from Caster \& Brooks (1956).

Remarks. The present authors prefer not to assign Chasmataspidida to a class (e.g. Merostomata) since the monophyly of the 'merostomes' has been questioned (Kraus 1976; Weygoldt \& Paulus 1979) and basal relationships within the Euchelicerata remain controversial (see section 6.2.). Three additional higher taxon names have been proposed for $C$. laurencii, all derived from the original ordinal and family names, and with authorship assigned to Caster \& Brooks (1956). Starabogatov's (1990) superorder Chasmataspidiformii is equivalent to Chasmataspidida, while his order Chasmataspidiformes is equivalent to Chasmataspididae, as is Bergström's (1975) proposed superfamily Chasmataspidacea. Given the small number of species involved, the present authors see no reason to adopt a complex hierarchy of names (see also Dunlop et al. 2001) and here they recognise a single order, Chasmataspidida, divided into two families: Chasmataspididae and Diploaspididae.

\section{Chasmataspididae Caster \& Brooks, 1956}

Emended diagnosis. Chasmataspids with a horseshoe-shaped prosomal dorsal shield, wider than long and with distinct genal spines. Preabdomen completely fused into a single plate, or buckler, with a broad axial region and serrated margins. Postabdomen long, weakly tapering and telson relatively elongate and lanceolate. Emended from Caster \& Brooks (1956).

Type and only genus. Chasmataspis Caster \& Brooks, 1956.

Remarks. In the Devonian family Diploaspididae, the prosomal dorsal shield is generally more subquadrate with only indistinct genal spines. The preabdomen is not clearly fused and lacks an axial region while the postabdomen tapers quite distinctly, and the telson is short, either styliform or spatulate in shape (Dunlop et al. 2001; Dunlop 2002a).

\section{Chasmataspis Caster \& Brooks, 1956}

Diagnosis. As for the family.

Type species. Chasmataspis laurencii Caster \& Brooks, 1956 (by monotypy).

\section{Chasmataspis laurencii Caster \& Brooks, 1956} Figs 1-8

1956 Chasmataspis laurencii Caster \& Brooks, pp. 171-9, text-figs A1 \& 2, pls. 12-20.

1967 Chasmataspis laurencii Caster \& Brooks; Crowson et al., p. 499.

1974 Chasmataspis laurencii Caster \& Brooks; Eldredge p. 36.

1979 Chasmataspis laurencii Caster \& Brooks; Bergström, p. 298.

1980 Chasmataspis laurencii Caster \& Brooks; Simonetta \& Delle Cave, p. 8, fig. 6.

1981 Chasmataspis laurencii Caster \& Brooks; Simonetta \& Delle Cave, p. 425, fig. 16.
1991 Chasmataspis laurencii Caster \& Brooks; Delle Cave \& Simonetta, p. 207, fig. 11B.

1993 Chasmataspis laurencii Caster \& Brooks; Selden, p. 299.

1999 Chasmataspis laurencii Caster \& Brooks; Dunlop et al., p. 161.

2000 Chasmataspis laurencii Caster \& Brooks; Anderson et al., p. 151.

2001 Chasmataspis laurencii Caster \& Brooks; Dunlop et al., p. 253.

2002b Chasmataspis laurencii Caster \& Brooks; Dunlop, pp. 122, fig. $5.3 \mathrm{~b}$.

Diagnosis. As for the family.

Material. Holotype, USNM 125099; paratypes 125101 and 125123, the latter an incomplete head shield and opisthosoma (not seen). USNM 125100 and 125106. Note that neither of these specimens was designated a paratype in the original description by Caster \& Brooks (1956, p. 179), even though they are listed as such on the present museum labels. In at least one case, the confusion seems to stem from Caster \& Brooks (1956, p. 189) labelling of their plates, which implies, incorrectly, that the isolated appendages belong to USNM 125123 (which is a paratype) when, in fact, they are preserved on a different slab, USNM 125106. Additional, generally less complete, material in the USNM and University of Cincinnati Museum (not seen). All from the 'sink hole deposit' at the foundations of the Douglas Dam, Sevier County, eastern Tennessee, USA. Type locality no longer exposed, but probably belonging to the Five Oaks Formation, Chickamauga Group (Middle Ordovician, Tremadoc-Caradoc).

Description of USNM 125099 (holotype). An almost complete specimen lacking the posterior end of postabdomen and telson (Figs $1 \&$ 2). Total length almost $60 \mathrm{~mm}$. Part and counterpart both show dorsal surface, but respectively in external and internal relief. Prosomal dorsal shield horseshoeshaped, length $11.6 \mathrm{~mm}$, maximum width across genal spines $22.9 \mathrm{~mm}$, marginal rim of shield $0.5 \mathrm{~mm}$ wide. Heart-shaped median eye tubercle central on dorsal shield, ovoid lateral eye tubercles lateral, and slightly anterior to, the median eye tubercle. Cardiac lobe trapezoid, behind the median eye tubercle, minimum width $3.5 \mathrm{~mm}$ widening posteriorly to about $7 \mathrm{~mm}$. Length of first tergite $1.9 \mathrm{~mm}$, width c. $16.5 \mathrm{~mm}$. Buckler formed from fusion of tergites 2, 3 and 4 with lengths of $3.3,4.0$ and $4.6 \mathrm{~mm}$, respectively. Preabdominal tergites with distinct axial region, widest anteriorly, $16.4 \mathrm{~mm}$, tapering posteriorly to c. $12.5 \mathrm{~mm}$ across tergite 3 , widening again posteriorly to $13.5 \mathrm{~mm}$ across the posterior margin of the buckler. All three preabdominal tergites with paired apodemes close to posterior margins of tergite. Margins of buckler lack signs of segmentation and consist of a marginal ridge defining a distinct border thrown into at least nine, bluntly rounded, fixed marginal spines. Enigmatic raised area in the posterior half of the buckler defined by a pair of not quite symmetrical, tapering, longitudinal lines across tergites 3 and 4 with a similarly enigmatic groove on the midline on tergites 2 and 3 . Postabdomen with eight preserved segments, total length c. $3.2 \mathrm{~mm}$. Postabdomen bent and segment boundaries sometimes difficult to distinguish, but postabdominal segments c. $3 \cdot 5-4.0 \mathrm{~mm}$ long and with distinct, paired muscle apodemes either side of the midline. Postabdomen tapers slightly from $9 \mathrm{~mm}$ wide anteriorly to $6 \mathrm{~mm}$ posteriorly. Weakly defined epimera on both the fifth and sixth postabdominal segments. Posteriormost segment incomplete, and both pretelsonic segment and telson absent.

Description of USNM 125101 (paratype). Another almost complete, but smaller, specimen, including a complete postabdomen (Figs 3, 4). Total length c. $45 \mathrm{~mm}$, including telson. 
Part and counterpart show dorsal surface in internal and external relief, respectively. Both also associated with a distorted and disarticulated ventral preabdominal shield. Prosomal dorsal shield horseshoe shaped, length $7.6 \mathrm{~mm}$, maximum width across the genal spines $12.7 \mathrm{~mm}$. Eye arrangement and cardiac lobe shape as in the holotype. Prosoma slightly disarticulated from, and preserved at an angle relative to, the opisthosoma, obscuring proportions of opisthosomal segment 1. Preabdominal buckler less well preserved than in the holotype, but has the same basic shape, axial region, apodemes and marginal spination. Segments 2-4 with lengths of $2 \cdot 0,2.2$ and $3.0 \mathrm{~mm}$ respectively. Postabdomen elongate, length $20.1 \mathrm{~mm}$, tapering slightly from $5.3 \mathrm{~mm}$ anteriorly to $3.3 \mathrm{~mm}$ posteriorly. Postabdominal segments rectangular, between $2 \cdot 1$ and $2.7 \mathrm{~mm}$ long, but pretelsonic segment (13) noticeably longer, $3.4 \mathrm{~mm}$. Some segments with weakly defined lateral epimera, but ornament indistinct. Telson lanceolate, $8.3 \mathrm{~mm}$ long, basally $2.9 \mathrm{~mm}$ wide, thinning sharply anteriorly and then continuing with subparallel margins to end in a bluntly pointed tip.

Specimen associated with a poorly preserved ventral preabdominal plate, rotated through c. $90^{\circ}$ relative to the specimen in dorsal view (Fig. 4b), which may or may not belong to the same animal. Specimen distorted, stretched along its lateral axis, with left and posterior margins poorly preserved. Anterior margin with a smoothly curving projection on the midline. Right lateral margin serrated with at least four teeth preserved. Weak transverse lineation. Cuticle ornamented with fine pits.

Description of USNM 125106. A single slab (incorrectly labelled a paratype) bearing a disarticulated prosomal dorsal shield and preabdomen, and more significantly, two disarticulated but almost complete appendages (Figs 5, 6). Smaller appendage (Figs 5a, 6a) comprises exopod only (podomeres 3-8). Two basal- most podomeres absent. Appendage distally chelate, total preserved length c. $13 \mathrm{~mm}$. Podomere 5 incomplete. Podomeres 4-6 rectangular, slightly longer than wide, with length increasing slightly distally: $1.5,1.7$ and $1.8 \mathrm{~mm}$, respectively. Podomere 7 substantially longer, $4.5 \mathrm{~mm}$, with distal end (length c. $2.3 \mathrm{~mm}$ ) drawn out inferiorly into the tapering fixed finger of the claw. Podomere 8 forms movable finger of claw, articulating in a superior position on podomere 7. Movable finger distinctly curved and tapering, at $3.2 \mathrm{~mm}$ longer than the corresponding fixed finger.

Second appendage (Figs 5b, 6b) larger, total preserved length c. $16 \mathrm{~mm}$, and stouter. Subtriangular basipod (podomere 1) bearing gnathobasic edge on the median surface. Basipod $3.8 \mathrm{~mm}$ long, rounded proximally and widening distally to a maximum of $2.1 \mathrm{~mm}$. Exopod short, flap-like, curving slightly with a similar curvature to the endopod, but poorly preserved in outline: length c. $2.7 \mathrm{~mm}$. Endopod almost complete, podomeres 2-6 more or less rectangular, widening slightly distally, lengths: $1.5,1.5,1.4,1.8$ and $1.9 \mathrm{~mm}$, respectively. Podomere 3 with angled articulations to adjacent podomeres forming the 'knee' joint. Podomere 7 substantially longer, $4.4 \mathrm{~mm}$, with distal $2.4 \mathrm{~mm}$ formed into the slender, slightly tapering fixed finger of the claw. Movable finger of the claw (podomere 8) absent.

Description of USNM 125100. A slab (incorrectly labelled a paratype) bearing an isolated ventral preabdominal plate bisected by an oblique crack (Fig. 7). Entire specimen slightly skewed. Cuticle ornamented with fine pits. Plate shield-shaped, length along midline $12 \mathrm{~mm}$. Maximum width $21.8 \mathrm{~mm}$, tapering posteriorly to $15.0 \mathrm{~mm}$. Anterior margin thrown into a smoothly curving projection. Posterior margin indented towards the anterior. Left lateral margin serrated with at least eight bluntly rounded teeth. Right margin poorly preserved and serration here absent. Transverse lines imply impression of preabdominal segmentation with three segments. At least two paired impressions (?muscle apodemes) to either side of the midline.

\section{Acknowledgements}

We thank Jann Thompson and Daniel Levin (USNM), Thomas Jellinek (Senckenberg Institute, Frankfurt), Andrew Ross (NHM, London), Valentina Talimaa (Vilnius), Christian Neumann (MB.A., Berlin) and Nigel Trewin (University of Aberdeen) for access to material in their care, and Mark Webster for providing casts of the Hickory Sandstone material made at the University of Cincinnati. We also thank Paul Selden, Greg Edgecombe, Erik Tetlie, Gregory Wahlman, Jan Bergström, Stig Bergström and Mark Sutton for valuable comments, and Markus Poschmann for information on the Alken and Hombach material. Carsten Brauckmann and an anonymous reviewer are thanked for numerous helpful suggestions. Vera Heinrich (Berlin) kindly prepared the photographs.

\section{References}

Anderson, L. I. \& Selden, P. A. 1997. Opisthosomal fusion and phylogeny of Palaeozoic Xiphosura. Lethaia 30, 19-31.

Anderson, L. I., Dunlop, J. A. \& Trewin, N. H. 2000. A Middle Devonian chasmataspid arthropod from Achanarras Quarry, Caithness, Scotland. Scottish Journal of Geology 36, 151-8.

Ausich, W. I. 1997. Regional encrinites: a vanished lithofacies. In Brett, C. E. \& Baird, G. C. (eds) Paleontological events: stratigraphic, ecological, and evolutionary implications, 509-19. New York, NY: Columbia University Press.

Beall, B. S. \& Labandeira, C. C. 1990. Macroevolutionary patterns of the Chelicerata and Tracheata. In Culver, S. J. (ed.) Arthropod paleobiology, short courses in palaeontology, No. 3, 257-84. Knoxville, Tennessee: The Paleontological Society.

Bergström, J. 1968. Eolimulus, a Lower Cambrian xiphosurid from Sweden. Geologiska Föreningens $i$ Stockholm Förhandlinger 90, 489-503.

Bergström, J. 1975. Functional morphology and evolution of xiphosurids. Fossils and Strata 4, 291-305.

Bergström, J. 1979. Morphology of fossil arthropods as a guide to phylogenetic relationships. In Gupta, A. P. (ed.) Arthropod phylogeny, 3-56. New York, NY: Van Nostrand Reinhold Co.

Bergström, J. 1980. Morphology and systematics of early arthropods. In Kraus, O. (ed.) Arthropoden-Phylogenie. Abhandlungen des Naturwissenschaftlichen Vereins in Hamburg (NF) 23, 7-42.

Bergström, J., Stürmer, W. \& Winter, G. 1980. Palaeoisopus, Palaeopantopus and Palaeothea, pycnogonid arthropods from the Lower Devonian Hunsrück Slate, West Germany. Paläontologische Zeitschrift 54, 7-54.

Bergström, S. M. 2000. Early Caradocian (460 M.Y.) marine cement, seawater temperature, and atmospheric carbon dioxide. Geological Society of America, Abstracts with Programs 32 (7), 299.

Braddy, S. J., Aldridge, R. J., Gabbott, S. E. \& Theron, J. N. 1999. Lamellate book-gills in a late Ordovician eurypterid from the Soom Shale, South Africa: support for a eurypterid-scorpion clade. Lethaia 32, 72-4.

Braddy, S. J., Selden, P. A. \& Doan Nhat, T. 2002. A new carcinosomatid eurypterid from the late Silurian of northern Vietnam. Palaeontology 45, 897-915.

Brauer, A. 1894. Beitäge zur Kenntnis der Entwicklungsgeschichte des Skorpions I. Zeitschrift für wissenschaftliche Zoologie 57, 402-32.

Buxton, B. H. 1917. Notes on the anatomy of arachnids. Journal of Morphology 29, 1-31.

Caster, K. E. \& Brooks, H. K. 1956. New fossils from the CanadianChazan (Ordovician) hiatus in Tennessee. Bulletins of American Palaeontology 36, 157-99.

Chlupáč, I. 1995. Lower Cambrian arthropods from the Paseky Shale (Barrandian area, Czech Republic). Journal of the Czech Geological Society 40, 9-36.

Crowson, R. A., Rolfe, W. D. I., Smart, J., Waterston, C. D., Willey, E. C. \& Wootton, R. J. 1967. Arthropoda: Chelicerata, Pycnogonida, Palaeoisopus, Myriapoda and Insecta. In The Fossil Record, 499-543. London: Geological Society of London. 
Delle Cave, L. \& Simonetta, A. M. 1991. Early Palaeozoic arthropods and problems of arthropod phylogeny; with some notes on taxa of doubtful affinity. In Conway Morris, S. \& Simonetta, A. M. (eds) The early evolution of Metazoa and the significance of problematic taxa, 189-244. Cambridge: Cambridge University Press.

Dunlop, J. A. 2002a. Arthropods from the Lower Devonian Severnya Zemlya Formation of October Revolution Island, Russia. Geodiversitas 24, 349-79.

Dunlop, J. A. 2002b. Phylogeny of Chelicerata. In Bousquets, J. L. \& Morrone, J. J. (eds) Biodiversidad, Taxonomía y Biogeografia de Artrópodos de Mexico, Vol. III, 117-41. Mexico City: Universidad Nacional Autónoma de México.

Dunlop, J. A. 2002c. Character states and evolution of the chelicerate claws. In Toft, S. \& Scharff, N. (eds) European arachnology 2000, 345-54. Aarhus: Aarhus University Press.

Dunlop, J. A., Anderson, L. I. \& Braddy, S. J. 1999. A new chasmataspid (Chelicerata: Chasmataspida) from the Lower Devonian of the Midland Valley of Scotland. Transactions of the Royal Society of Edinburgh: Earth Sciences 89 (for 1998), 161-5.

Dunlop, J. A., Poschmann, M. \& Anderson, L. I. 2001. On the Emsian (Early Devonian) arthropods of the Rhenish Slate Mountains: 3. The chasmataspidid Diploaspis. Paläontologische Zeitschrift 75, 253-69.

Dunlop, J. A. \& Braddy, S. J. 2001. Scorpions and their sister-group relationships. In Fet, V. \& Selden, P. A. (eds) Scorpions 2001, in memoriam Gary A. Polis, 1-24. Burnham Beeches: The British Arachnological Society.

Dunlop, J. A. \& Selden, P. A. 1997. The early history and phylogeny of the chelicerates. In Fortey, R. A. \& Thomas, R. H. (eds) Arthropod relationships, 221-35. Systematics Association Special Volume 55. London: Chapman and Hall.

Dunlop, J. A. \& Webster, M. 1999. Fossil evidence, terrestrialization and arachnid phylogeny. Journal of Arachnology 27, 86-93.

Edgecombe, G. D. \& Ramsköld, L. 1999. Relationships of Cambrian Arachnata and the systematic position of Trilobita. Journal of Paleontology 73, 263-87.

Eldredge, N. 1974. Revision of the Synziphosurina (Chelicerata, Merostomata), with remarks on merostome phylogeny. American Museum Novitates 2543, 1-41.

Giribet, G., Edgecombe, G. D., Wheeler, W. C. \& Babbitt, C. 2002. Phylogeny and systematic position of Opiliones: a combined analysis of chelicerate relationships using morphological and molecular data. Cladistics 18, 5-70.

Hammen, L. van der. 1989. An introduction to comparative arachnology. The Hague: SPB Academic Publishing.

Heymons, R. 1901. Die Entwicklungsgeschichte der Scolopender. Zoologica, 33, 244 pp.

Hou X.-g. \& Bergström, J. 1997. Arthropods from the Lower Cambrian Chenjiang fauna, southwest China. Fossils and Strata $\mathbf{4 5}$, $1-116$.

Janssens, A. 1973. Stratigraphy of the Cambrian and Lower Ordovician rocks in Ohio. Division of the Geological Survey Bulletin 64, $1-197$.

Jeram, A. J. 1998. Phylogeny, classification and evolution of Silurian and Devonian scorpions. In Selden, P. A. (ed.) Proceedings of the 17th European Colloquium of Arachnology, Edinburgh 1997, 17-31. Burnham Beeches: The British Arachnological Society.

Kjellesvig-Waering, E. N. \& Heubusch, C. A. 1962. Some Eurypterida from the Ordovician and Silurian of New York. Journal of Paleontology 36, 211-21.

Kraus, O. 1976. Zur phylogenetischen Stellung und Evolution der Chelicerata. Entomologica Germanica 3, 1-12.

Laurence, R. A. 1944. An early Ordovician sinkhole deposit of volcanic ash and fossiliferous sediments in east Tennessee. Journal of Geology 52, 235-49.

Millot, J. 1949. Morphologie générale et anatomie interne. In Grassé P.-P. (ed.) Traité de Zoologie, VI, 263-319. Paris: Masson et $\mathrm{Cie}$.

Novojilov, N. 1959. Mérostomes du Dévonian inférieur et moyen de Sibérie. Annals Société Géologique du Nord 78, 241-58.

Orr, P. J., Briggs, D. E. G., Siveter, D. J. \& Siveter, D. J. 2000a. Three dimensional preservation of a non-biomineralised arthropod in concretions of Silurian volcaniclastics from Herefordshire, England. Journal of the Geological Society 157, 173-86.

Orr, P. J., Siveter, D. J., Briggs, D. E. G., Siveter, D. J. \& Sutton, M. D. 2000b. A new arthropod from the Konservat-Lagerstätte of Herefordshire, UK. Proceedings of the Royal Society of London Series B 267, 1497-504.

Petrunkevitch, A. I. 1922. The circulatory system and segmentation in Arachnida. Journal of Morphology 36, 156-89.
Poschmann, M., Anderson, L. I. \& Dunlop, J. A. in press. A remarkable chelicerate fauna (Arthropoda, Chelicerata) including the oldest record of phalangiotarbid arachnids from the Early Devonian (Siegenian) of the Westerwald Area (Rhenish Massif, Germany). Journal of Paleontology.

Racheboeuf, P. R., Vannier, J. \& Anderson, L. I. 2002. A new three-dimensionally preserved xiphosuran chelicerate from the Montceau-les-Mines Lagerstätte (Carboniferous, France). Palaeontology 45, 125-47.

Raw, F. 1957. Origin of chelicerates. Journal of Paleontology 31, 139-92.

Roberson, K. E. 1994. Stratigraphy and depositional history of Middle Ordovician peritidal carbonate rocks overlying the post-Knox unconformity, East Tennessee. Unpublished PhD thesis, University of Tennessee.

Savory, T. H. 1971. Evolution in the Arachnida. Watford: Merrow Monographs.

Schultka, S. 2000. Zur Palökologie der Euproopiden im Nordwestdeutschen Oberkarbon. Mitteilungen aus dem Museum für Naturkunde Berlin, Geowissenschaftliche Reihe 3, 87-98.

Selden, P. A. 1981. Functional morphology of the prosoma of Baltoeurypterus tetragonophthalmus (Fischer) (Chelicerata: Eurypterida). Transactions of the Royal Society of Edinburgh: Earth Sciences 72, 9-48.

Selden, P. A. 1993. Arthropoda (Aglaspidida, Pycnogonida and Chelicerata) In Benton, M. J. (ed.) The Fossil Record 2, 297-320. London: Chapman and Hall.

Selden, P. A. \& Dunlop, J. A. 1998. Fossil taxa and relationships of chelicerates. In Edgecombe, G. (ed.) Arthropod fossils and phylogeny, 303-31. New York, NY: Columbia University Press.

Selden, P. A. \& Siveter, D. J. 1987. The origin of the limuloids. Lethaia 20, 383-92.

Shultz, J. W. 1990. Evolutionary morphology and phylogeny of Arachnida. Cladistics 6, 1-38.

Shultz, J. W. 2001. Gross muscular anatomy of Limulus polyphemus (Xiphosura, Chelicerata) and its bearing on evolution in Arachnida. Journal of Arachnology 29, 283-303.

Simonetta, A. \& Delle Cave, L. 1978. Una possible interpretazione filogenetica degli arthropodi paleozoici. Bollettino di Zoologia 45, 87-90.

Simonetta, A. \& Delle Cave, L. 1980. The phylogeny of the palaeozoic Arthropods. Bollettino di Zoologia 47 (suppl.), 1-19.

Simonetta, A. \& Delle Cave, L. 1981. An essay in the comparative and evolutionary morphology of Palaeozoic arthropods. Origine die grandi Phyla di Metazoi. Academia Nazionale die Lincei. Atti die Convegni Lincei 49, 389-439.

Starobogatov, Y. I. 1990. The systematics and phylogeny of the lower chelicerates (a morphological analysis of the Paleozoic groups). [English translation from Russian.] Paleontologicheskii Zhurnal 1, 4-17.

Steinhauff, D. M. \& Walker, K. R. 1995. Recognizing exposure, drowning, and 'missed beats': Platform-interior to platformmargin sequence stratigraphy of Middle Ordovician limestones, East Tennessee. Journal of Sedimentary Research B65 (2), 183207.

Størmer, L. 1955. Merostomata. In Moore, R. C. (ed.) Treatise on invertebrate paleontology, part $P$, Arthropoda 2, 4-41. Boulder, Colorado and Lawrence, Kansas: Geological Society of America and University of Kansas Press.

Størmer, L. 1972. Arthropods from the Lower Devonian (Lower Emsian) of Alken an der Mosel, Germany. Part 2: Xiphosura. Senckenbergiana lethaea 53, 1-29.

Stürmer, W. \& Bergström, J. 1981. Weinbergina, a xiphosuran arthropod from the Devonian Hunsrück Slate. Paläontologische Zeitschrift 55, 237-55.

Tetlie, O. E. \& Braddy, S. J. 2004. The first Silurian chasmataspid, Loganamaraspis dunlopi gen. et sp. nov. (Chelicerata: Chasmataspidida) from Lesmahagow, Scotland, and its implications for eurypterid phylogeny. Transactions of the Royal Society of Edinburgh: Earth Sciences 94 (for 2003), 227-34.

Tollerton, V. P., Jr. 1989. Morphology, taxonomy and classification of the order Eurypterida Burmeister, 1843. Journal of Paleontology 63, 642-57.

Wahlman, G. P. \& Caster, K. E. 1978. Bearing of new Texas Upper Cambrian arthropods on merostome classification. Geological Society of America, Abstracts with Programs 10 (6), 268.

Walossek, D. \& Müller, K. J. 1997. Cambrian 'Orsten'-type arthropods and the phylogeny of Crustacea. In Fortey, R. A. \& Thomas, R. H. (eds) Anthropod Relationships, 139-53. Systematic Association Special Volume 55. London: Chapman and Hall. 
Waloszek, D. \& Dunlop, J. A. 2002. A larval sea spider (Arthropoda: Pycnogonida) from the Upper Cambrian 'Orsten' of Sweden, and the phylogenetic position of pycnogonids. Palaeontology 45, $421-46$.
Weygoldt, P. \& Paulus, H. F. 1979. Untersuchungen zur Morphologie, Taxonomie und Phylogenie der Chelicerata. Zeitschrift für zoologische Systematik und Evolutionsforschung 17, 85-115, 177200.

JASON A. DUNLOP, Institut für Systematische Zoologie, Museum für Naturkunde der HumboldtUniversität zu Berlin, D-10115 Berlin, Germany.

e-mail: jason.dunlop@museum.hu-berlin.de

LYALL I. ANDERSON, Department of Geology and Zoology, National Museums of Scotland, Chambers Street, Edinburgh, EH1 1JF, UK.

e-mail: landerson@nms.ac.uk

SIMON J. BRADDY, Department of Earth Sciences, University of Bristol, Queen's Road, Bristol, BS8 1RJ, UK.

e-mail: S.J.Braddy@bristol.ac.uk

MS received 1 October 2002. Accepted for publication 10 July 2003. 